\title{
Electrons selective uptake of a metal-reducing bacterium Shewanella oneidensis MR-1 from ferrocyanide
}

Zheng, Zhiyong; Xiao, Yong; Wu, Ranran; Christensen, Hans Erik Mølager; Zhao, Feng; Zhang, Jingdong

Published in:

Biosensors and Bioelectronics

Link to article, DOI:

10.1016/j.bios.2019.111571

Publication date:

2019

Document Version

Peer reviewed version

Link back to DTU Orbit

Citation (APA):

Zheng, Z., Xiao, Y., Wu, R., Christensen, H. E. M., Zhao, F., \& Zhang, J. (2019). Electrons selective uptake of a metal-reducing bacterium Shewanella oneidensis MR-1 from ferrocyanide. Biosensors and Bioelectronics, 142, [111571]. https://doi.org/10.1016/j.bios.2019.111571

\section{General rights}

Copyright and moral rights for the publications made accessible in the public portal are retained by the authors and/or other copyright owners and it is a condition of accessing publications that users recognise and abide by the legal requirements associated with these rights.

- Users may download and print one copy of any publication from the public portal for the purpose of private study or research.

- You may not further distribute the material or use it for any profit-making activity or commercial gain

- You may freely distribute the URL identifying the publication in the public portal 
1 Electrons selective uptake of a metal-reducing bacterium Shewanella oneidensis MR-1 from

2 ferrocyanide

3 Zhiyong Zheng, ${ }^{\mathrm{a}}$ Yong Xiao, ${ }^{\mathrm{a}}$ Ranran Wu, ${ }^{\mathrm{a}, \mathrm{c}}$ Hans E. Mølager Christensen, ${ }^{\mathrm{a}}$ Feng Zhao, ${ }^{\mathrm{b}}$ and Jingdong Zhang*,a

4 aDepartment of Chemistry, Technical University of Denmark, Kemitorvet, Building 207, DK-2800 Kongens

5 Lyngby, Denmark.

$6 \quad$ bAS Key Laboratory of Urban Pollutant Conversion, Institute of Urban Environment, Chinese Academy of

7 Sciences, 1799 Jimei Road, Xiamen 361021, China.

$8 \quad$ 'Tianjin Institute of Industrial Biotechnology, Chinese Academy of Sciences, 32 West 7th Avenue, Tianjin

9 Airport Economic Area, Tianjin 300308, China.

10 
Abstract

The extracellular electron transfer of Shewanella oneidensis MR-1 (MR-1) has been extensively studied due to the importance of the biosensors and energy applications of bioelectrochemical systems. However, the oxidation of metal compounds by MR-1, which represents the inward extracellular electron transfer from extracellular electron donors into the microbe, is barely understood. In this study, MR-1 immobilized on an electrode electrocatalyzes the oxidation of $\left[\mathrm{Fe}(\mathrm{CN})_{6}\right]^{4-}$ to $\left[\mathrm{Fe}(\mathrm{CN})_{6}\right]^{3-}$ efficiently and selectively. The selectivity depends on midpoint potential and overall charge(s) of redox molecules. Among 12 investigated redox molecules, the negatively charged molecules with high midpoint potentials, i.e., $\left[\mathrm{Ru}(\mathrm{CN})_{6}\right]^{4-}$ and $\left[\mathrm{Fe}(\mathrm{CN})_{6}\right]^{4-}$, show strong electrocatalysis. Neither reference bacteria (Escherichia coli K-12 nor Streptococcus mutans) electrocatalyze the oxidation of $\left[\mathrm{Fe}(\mathrm{CN})_{6}\right]^{4-}$. The electrocatalysis decays when MR-1 is covered with palladium nanoparticles presumptively involved with cytochromes $c$. However, cytochromes $c$ MtrC and OmcA on MR-1 do not play an essential role in this process. The results support a model that $\left[\mathrm{Fe}(\mathrm{CN})_{6}\right]^{4-}$ donor electrons to MR1 by interacting with undiscovered active sites and the electrons are subsequently transferred to the electrode through the mediating effect of $\left[\mathrm{Fe}(\mathrm{CN})_{6}\right]^{4-/ 3-}$. The selective electron uptake by MR-1 provides valuable insights into the fundamental insights of the applications of bioelectrochemical systems and the detection of specific redox molecules.

Keywords: electrocatalysis; Shewanella; bioelectrochemical systems; extracellular electron transfer; ferrocyanide; cytochromes $c$

\section{Introduction}

The extracellular electron transfer (EET) has been widely investigated due to the application of bioelectrochemical systems (BESs) in biosensor (Prévoteau et al. 2019; Zhang and Angelidaki 2012b) and energy harvest (Sun et al. 2017; Wang et al. 2015; Zhang and Angelidaki 2012a). A deep understanding of the mechanism of BESs is the prerequisite of optimized performance of the applications. In EET, electrochemical active bacteria $(\mathrm{EAB})$ exchange electrons with external redox compounds, electrodes or even other microorganisms via short-distance direct electron transfer through redox proteins on cell membrane, long- 
distance electron transfer through conductive nanowires, and indirect electron transfer through mediators (ElNaggar et al. 2010; Kumar et al. 2012; Schröder and Harnisch 2017; Xiao et al. 2017; Zheng et al. 2018).

As a model EAB, metal-reducing bacterium Shewanella oneidensis MR-1 (MR-1) transport electrons from the cells to extracellular electron acceptors, such as $\mathrm{Cu}$ (II) ions (Kimber et al. 2018), thiosulfate (Sheetal et al. 2011), fumarate (Pinchuk et al. 2011), nitrate (Cruz-García et al. 2007), Mn(IV) oxides (J.M. and C.R. 2003), and Fe(III) (hydro)oxides (Marsili et al. 2008). Several cytochromes $c$ in the cell membrane are involved in the EET of MR-1 by OmcA-MtrCAB respiratory pathway (Hartshorne et al. 2009; Lovley 2012; Vellingiri et al. 2018). Firstly, CymA (an inner membrane cytochrome $c$ ) obtain electrons by oxidizing quinol, and the electrons are given to MtrA (an inner membrane decaheme cytochrome $c$ ) via the periplasmic fumarate reductase FccA and small tetraheme cytochrome. Secondly, the electrons are further delivered through a trans-outer membrane protein complex formed by MtrA, MtrB (a transmembrane protein), and MtrC to the surface of MR-1. Thirdly, on the cellular surface, a complex of MtrC and OmcA (decaheme cytochromes $c$ on the outer cell membrane) transfer the electrons to extracellular electron acceptors (Kumar et al. 2017; Shi et al. 2007). Recently, MtrA is reported to fully extend through MtrB (Edwards et al. 2018), so MtrA is possibly exposed to milieu when MtrC and OmcA are knocked out.

In addition to outward EET, e.g. the reduction of insoluble Fe(III)/Mn(IV) (hydr)oxides by EAB (such as MR1 and Geobacter sulfurreducens) (Coker et al. 2010; Tan et al. 2016; Wang et al. 2019), the inward EET also has been reported, in which microbes take electrons from electron donors in the environment and transport the electrons into the cells. An iron-oxidizing photoautotroph Rhodopseudomonas palustris TIE-1 is able to accept electrons from an electrode poised at $+100 \mathrm{mV}$ vs. standard hydrogen electrode (SHE), coupling with the reduction of carbon dioxide (Bose et al. 2014). Moreover, an outer membrane-bound cytochrome $c$ Cyc2 is regarded as the first electron acceptor in the iron respiratory chain of the acidophilic bacterium Acidithiobacillus ferrooxidans, with a redox potential of as high as $560 \mathrm{mV}$ vs. SHE (Castelle et al. 2008).

The outward EET of MR-1 can be reversed in OmcA-MtrCAB pathway, i.e., this pathway can transport electrons from electrodes into the cells (Ross et al. 2011). Additionally, Shewanella strain 4t3-1-2LB with an ability to use metallic iron as the sole electron donor was discovered (Philips et al. 2018). Notably, some metal- 
reducing bacteria have been discovered to oxidize $\mathrm{Mn}$ (II). Shewanella sp. was found to be a Mn(II)-oxidizers in

63

a seamount (Staudigel et al. 2006). Moreover, other Shewanella strains have been reported to play a role in metal oxidation, including manganese oxidation (Blöthe et al. 2015; Bräuer et al. 2011; DiChristina and DeLong 1993) and Fe-oxidizing (Yli-Hemminki et al. 2014). According to a detailed study, five Shewanella strains (Shewanella oneidensis MR-1, Shewanella putrefaciens CN-32, Shewanella putrefaciens 200, Shewanella loihica PV-4, and Shewanella denitrificans OS217) oxidized Mn(II) and produced manganese oxide nanoparticles under aerobic conditions. The manganese oxide nanoparticles were reduced by the same bacteria when lactate was added, and oxygen was degassed (Wright et al. 2016). Multicopper oxidase enzymes are involved in oxidations, including Mn(II) oxidation (Soldatova et al. 2012). Additionally, laccases, a member of multicopper oxidase enzymes, have been discovered in Shewanella species (Sinirlioglu et al. 2013; Wu et al. 2009). It is reasonable to assume that laccases contribute to the $\mathrm{Mn}$ (II) oxidation since redox potential of some laccases can be more than $0.7 \mathrm{~V}$ vs SHE (Shleev et al. 2004; Zimbardi et al. 2016) or even 0.8 V vs SHE (Piontek et al. 2002). Some laccases produced by fungi actually oxidized Mn(II) (Höfer and Schlosser 1999). Furthermore, peroxidases from fungi were also involved in Mn(II) oxidation (Palma et al. 2000). However, it is not clear whether MR-1 is able to directly take electrons extracellularly from iron compounds. There are more than 39 genes relevant to cytochromes $c$ in the genome of MR-1 (Heidelberg et al. 2002), but only six of cytochromes $c$ (MtrA, MtrC, OmcA, CymA, small tetraheme cytochrome, and FccA) have been discovered in the outward EET. The rest cytochromes $c$ and potential laccases may offer other function to MR-1 in EET. Thus, more effort is needed to explore the possibility of other EET forms to disclose the role and function of MR-1 in the environment.

In this study, we find that MR-1 can take electrons from $\left[\mathrm{Fe}(\mathrm{CN})_{6}\right]^{4-}$ and catalytically electrooxidize it to $\left[\mathrm{Fe}(\mathrm{CN})_{6}\right]^{3-}$. No such electrocatalysis is found in reference bacteria, for example, Escherichia coli $\mathrm{K}-12$ and Streptococcus mutans. Interestingly, we notice that MR-1 electrocatalyzes only negatively charged redox molecules with a high midpoint potential, such as $\left[\mathrm{Fe}(\mathrm{CN})_{6}\right]^{4-}$ and $\left[\mathrm{Ru}(\mathrm{CN})_{6}\right]^{4-}$, among 12 redox molecules including mediators (e.g., riboflavin, $\left[\mathrm{Ru}\left(\mathrm{NH}_{3}\right)_{6}\right] \mathrm{Cl}_{3}$, and resorufin). Furthermore, the electrocatalysis is mainly attributed to the inherent catalytic properties of the active sites rather than the respiration of MR-1. A model with 
the concurrence of the electrocatalytic oxidation of $\left[\mathrm{Fe}(\mathrm{CN})_{6}\right]^{4-}$ by MR-1 and the mediating process of $\left[\mathrm{Fe}(\mathrm{CN})_{6}\right]^{4-/ 3-}$ is therefore proposed.

\section{Experimental Section}

\subsection{Chemicals.}

Luria-Bertani broth (LB, $10 \mathrm{~g} \mathrm{~L}^{-1}$ tryptone, $5 \mathrm{~g} \mathrm{~L}^{-1}$ yeast extract, $\left.5 \mathrm{~g} \mathrm{~L}^{-1} \mathrm{NaCl}\right), \mathrm{Na}_{2} \mathrm{HPO}_{4} \cdot 12 \mathrm{H}_{2} \mathrm{O}(99 \sim 101 \%)$, Nafion DE 1021 (10\%), $\mathrm{KCl}(\geq 99.0 \%), 6$-Mercaptocaproic acid (90\%), cytochrome $c$ (from equine heart, >95\%), $\mathrm{KH}_{2} \mathrm{PO}_{4}(98 \sim 100.5 \%), \mathrm{NH}_{4} \mathrm{Cl}(\geq 99.5 \%), \mathrm{CaCl}_{2} \cdot 2 \mathrm{H}_{2} \mathrm{O}(99 \%)$, hydroxymethylferrocene (97\%), sodium DL-lactate (60\%), $\mathrm{Na}_{2} \mathrm{PdCl}_{4}(98 \%)$, and glutaraldehyde (25\%) were obtained from Sigma-Aldrich, Germany. Ferrocenecarboxylic acid $(\geq 97.0 \%(\mathrm{Fe}))$ was from Sigma-Aldrich, China. Riboflavin $(\geq 98 \%)$ and aminoferrocene ( $\geq 98.0 \%$ ) were purchased from Sigma-Aldrich, Japan. Hexaammineruthenium(III) chloride (98\%), resorufin (Dye content $95 \%$ ), 1,9-Dimethyl-methylene blue zinc chloride double salt (Dye content 80\%), glucose ( $\geq 99 \%$ ), and potassium hexachloroiridate (technical grade) were produced by Sigma-Aldrich, USA. Potassium hexacyanoferrate(II) trihydrate (99.0 102.0\%) was from Merck, Germany. $\mathrm{NaH}_{2} \mathrm{PO}_{4} \cdot 2 \mathrm{H}_{2} \mathrm{O}(\geq 99.0 \%)$, $\mathrm{NaCl}(\geq 99.5 \%$ ), and 2,2'-Azino-bis(3-ethylbenzothiazoline-6-sulfonic acid) diammonium salt ( $\geq 98.0 \%)$ were supplied by Fluka, Germany. $\mathrm{MgSO}_{4} \cdot 7 \mathrm{H}_{2} \mathrm{O}(99.8 \%)$ and potassium hexacyanoferrate(III) $(\geq 99.5 \%)$ were from Riedel-de-Haën, France. 1,1'-Ferrocenedicarboxylic acid (>97.0\%) was obtained from Fluka, Switzerland. Potassium hexacyanoruthenate(II) hydrate (Ru 23.0\% min) was provided by Alfa Aesar, USA. Absolute ethanol (100\%) was produced by VWR Chemicals, France. All chemicals were used as received without further purification. Aqueous solutions were prepared with MilliQ water $\left(18.2 \mathrm{M} \Omega \mathrm{cm}\right.$, arium ${ }^{\circledR}$ pro VF system, Sartorius AG, Germany).

\subsection{Culture and collection of Shewanella oneidensis MR-1.}

Shewanella oneidensis MR-1 wild type (MR-1) and Shewanella oneidensis MR-1 AomcA/mtrC mutant (MR-1 mutant) were original from Prof. K. H. Nealson at the University of Southern California (Bretschger et al. 2007) and further developed in Prof. Feng Zhao's lab at Institute of Urban Environment (IUE), CAS (Wu et al. 2013). These strains were introduced into the Department of Chemistry, Technical University of Denmark in 2014. 
112 Briefly, strain medium $(1.0 \mathrm{~mL})$ was taken from $4^{\circ} \mathrm{C}$ refrigerator and added to Luria-Bertani broth $(100 \mathrm{~mL})$.

113 Then the medium was incubated in a shaker controlled at $30^{\circ} \mathrm{C}$ (for MR-1 and MR-1 mutant) or $37^{\circ} \mathrm{C}$ (for $E$. coli

114 K-12) with a speed of $100 \mathrm{rpm}$ for about $22 \mathrm{~h}$. The bacteria were collected by centrifuging at a speed of 4000

$115 \mathrm{rpm}$ for $5 \mathrm{~min}$. Afterward, the bacteria were re-suspended with $50 \mathrm{mM}$ phosphate buffered saline [PBS, pH 7.0;

$\left.116 \mathrm{NaH}_{2} \mathrm{PO}_{4} \cdot 2 \mathrm{H}_{2} \mathrm{O}\left(3.04 \mathrm{~g} \mathrm{~L}^{-1}\right), \mathrm{Na}_{2} \mathrm{HPO}_{4} \cdot 12 \mathrm{H}_{2} \mathrm{O}\left(10.92 \mathrm{~g} \mathrm{~L}^{-1}\right)\right]$ following centrifugation. The resuspension and

117 centrifugation were repeated three times to remove the excreta on the surface of bacteria. Bacteria precipitate

$118(5.0 \mu \mathrm{L})$ was mixed and cast on electrode surface $(\varnothing 4.0 \mathrm{~mm})$ and dried in a fume cupboard under room

119 temperature. For chronoamperometry, Nafion solution $(5.0 \mu \mathrm{L}, 1 \%)$ was also added into bacteria precipitate

120 before cast on electrode surface.

\section{$121 \quad$ 2.3. Electrochemical measurements.}

122 Cyclic voltammetry (CV) was performed using a potentiostat (Autolab PGSTAT12, Eco Chemie, Utrecht, The

123 Netherlands) in a three-electrode mode. Glassy carbon electrode (GCE) or gold electrode (Au) and platinum wire

124 were used as working electrode and counter electrode respectively. The reference electrode was an $\mathrm{Ag} / \mathrm{AgCl}$

125 electrode with saturated $\mathrm{KCl}$ (0.197 V vs. Standard hydrogen electrode, SHE). The electrolyte was PBS (50 mM,

$126 \mathrm{pH}$ 7.0). Oxygen in the electrolyte was removed by bubbling argon (High Purity $5 \mathrm{~N}$ ) for 30 min prior to

127 measurement. CVs were recorded with a scan rate of $10 \mathrm{mV} \mathrm{s}^{-1}$ (unless stated otherwise) and a step of $2 \mathrm{mV}$,

128 starting from open circuit potential unless otherwise specified. For differential pulse voltammetry (DPV), the

129 potential window was $-0.6 \mathrm{~V}$ to $0.4 \mathrm{~V}$ vs. $\mathrm{Ag} / \mathrm{AgCl}$ with the scan rate of $10 \mathrm{mV} \mathrm{s}^{-1}, 5 \mathrm{mV}$ pulse increments, 25

$130 \mathrm{mV}$ pulse amplitude, and $50 \mathrm{~ms}$ pulse width. The electrochemical analysis was repeated in at least triplicate and

131 typical results were presented.

\section{3. Results}

$134\left[\mathrm{Fe}(\mathrm{CN})_{6}\right]^{4-/ 3-}$ is a redox couple with standard redox potential at $0.164 \mathrm{~V}$ vs. $\mathrm{Ag} / \mathrm{AgCl}$ (all electrode potentials 135 are measured against $\mathrm{Ag} / \mathrm{AgCl}$ unless stated otherwise), according to the one-electron transfer reaction below: 
137 Either $\left[\mathrm{Fe}(\mathrm{CN})_{6}\right]^{3-}$ or $\left[\mathrm{Fe}(\mathrm{CN})_{6}\right]^{4-}$ can exchange electrons with bare electrode such as glassy carbon electrode

$138(\mathrm{GCE})$ and gold electrode $(\mathrm{Au})$ with a fast and reversible oxidation of $\left[\mathrm{Fe}(\mathrm{CN})_{6}\right]^{4-}$ or reduction of $\left[\mathrm{Fe}(\mathrm{CN})_{6}\right]^{3-}$,

139 presenting one symmetric voltammetry (Fig. 1 left). In fact, $\left[\mathrm{Fe}(\mathrm{CN})_{6}\right]^{3-}$ is extensively utilized as an electron

140 acceptor added to cathodic chambers in bioelectrochemical systems (BESs) (Wang et al. 2013; Xiao et al. 2013;

141 Yang et al. 2017; Yu et al. 2011). The reversibility and rate of electron transfer can be measured by peak-peak

142 potential separation in cyclic voltammetry (CV) at a given scan rate (Allen and Larry 2001). When an electrode

143 surface is covered by an insulator or a less conductive layer, interfacial electron transfer rate reduces, with low

144 current and broad peak-peak potential separation, or the vanishing of both redox peaks. Electron transfer

145 decreases exponentially with the increase of the layer thickness (Chi et al. 2001). As an example, the thickness

146 of 6-Mercaptohexanoic acid is only about $1 \mathrm{~nm}$, but the electrochemical signal from the cycling between

$147\left[\mathrm{Fe}(\mathrm{CN})_{6}\right]^{4-}$ and $\left[\mathrm{Fe}(\mathrm{CN})_{6}\right]^{3-}$ has been completely blocked (Fig. 1 middle).

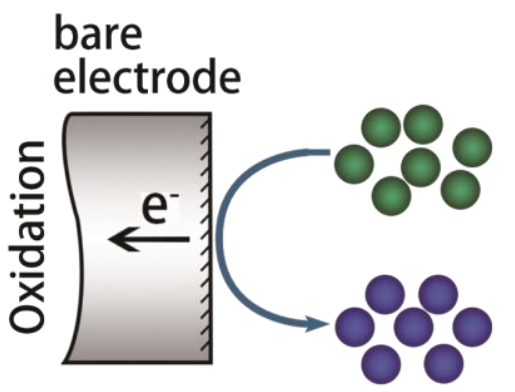

$\mathrm{Au} / 6 \mathrm{C}-\mathrm{HS}$
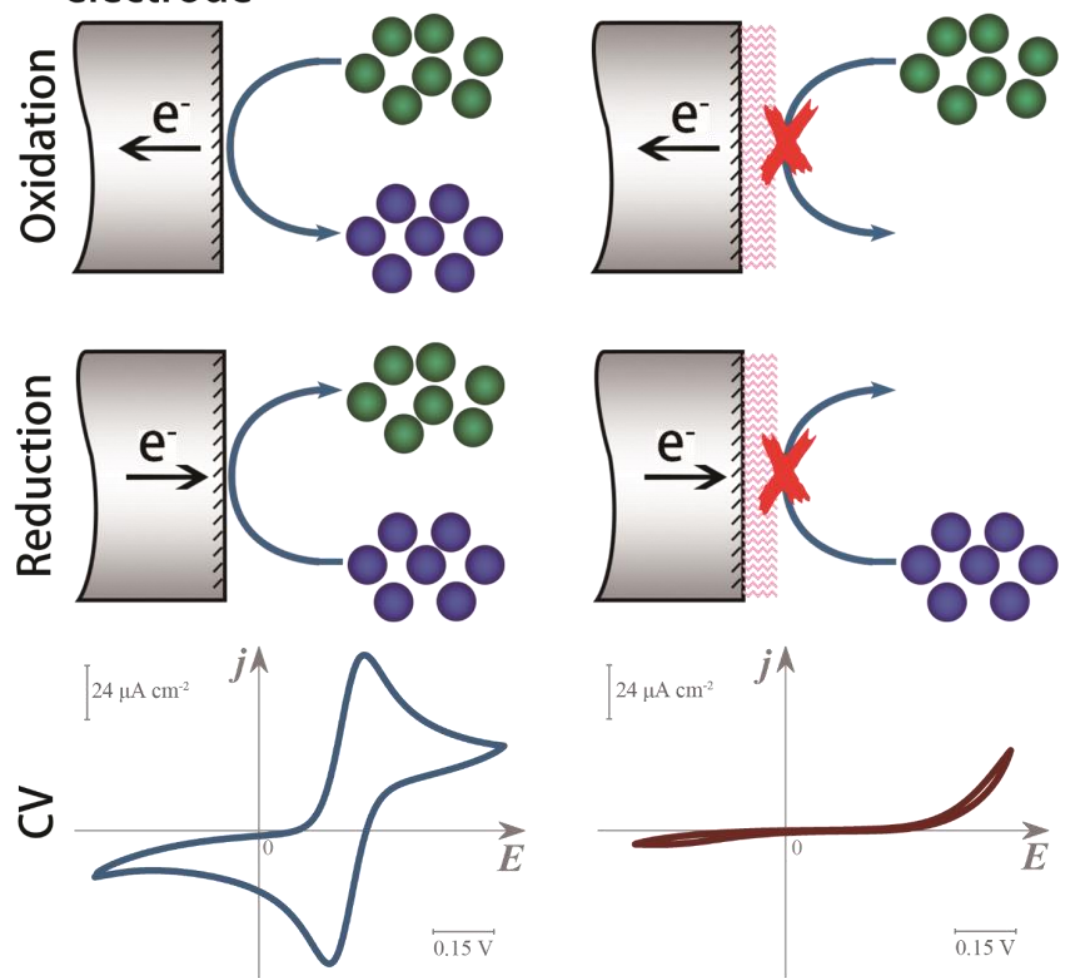

148
$\mathrm{O}\left[\mathrm{Fe}(\mathrm{CN})_{6}\right]^{4}$
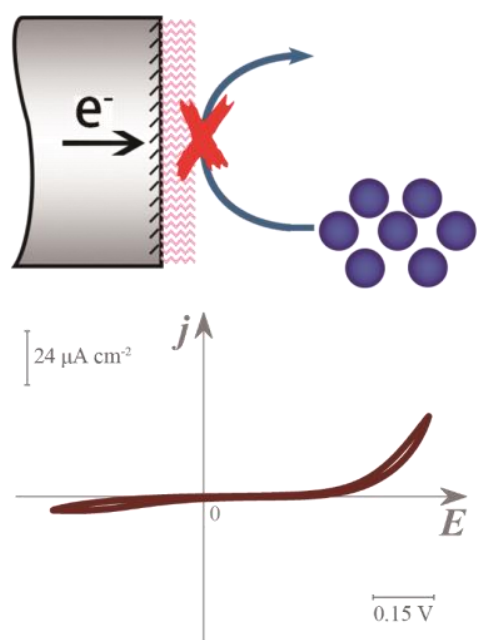

6C-HS
GCE/MR-1
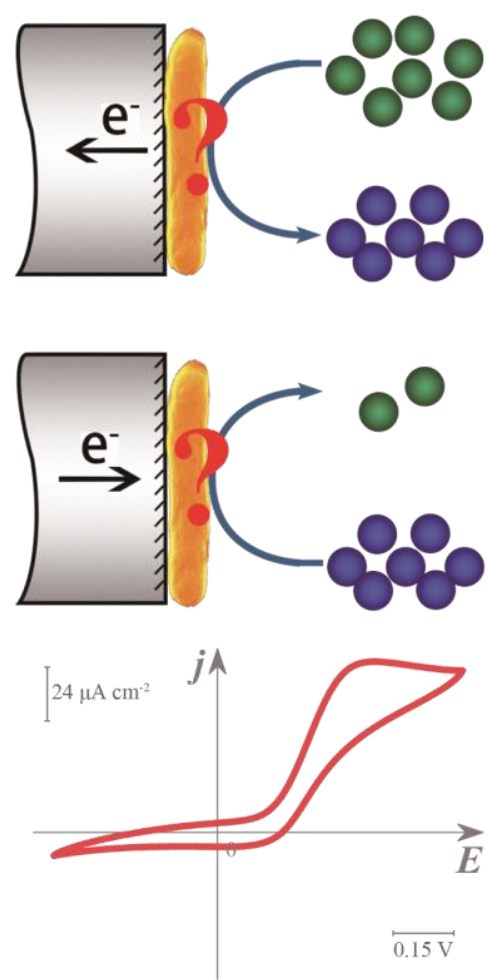

S. oneidesis MR-1 
149 Fig. 1. Conversion of $\left[\mathrm{Fe}(\mathrm{CN})_{6}\right]^{4-/ 3-}$ on different electrodes. Reversible conversion of $\left[\mathrm{Fe}(\mathrm{CN})_{6}\right]^{4-/ 3-}$ on a bare

150 electrode (left), nonreversible conversion of $\left[\mathrm{Fe}(\mathrm{CN})_{6}\right]^{4-3-}$ on a 6-Mercaptohexanoic acid modified gold electrode

151 (Au/6C-HS, middle), and electrocatalysis oxidation of $\left[\mathrm{Fe}(\mathrm{CN})_{6}\right]^{4-}$ to $\left[\mathrm{Fe}(\mathrm{CN})_{6}\right]^{3-}$ on a MR-1 coated on GCE

152 (GCE/MR-1, right). Scan rate $10 \mathrm{mV} \mathrm{s}^{-1}$. Electrolyte $50 \mathrm{mM}$ PBS (pH 7.0).

153 Interestingly, a strong anodic peak appears on voltammetry similar to that on bare electrode when MR-1 cells

154 are coated on a GCE, but the cathodic peak almost vanished (Fig. 1 right). MR-1 is a model dissimilatory metal-

155 reducing bacterium with a rod shape, as the cluster of MR-1 cells showed under atomic force microscopy (AFM)

156 (Fig. 2A). The length and diameter of MR-1 are in a range of $2 \sim 5 \mu \mathrm{m}$ and $0.4 \sim 0.7 \mu \mathrm{m}$ respectively, in agreement

157 with the analysis of SEM and TEM. Pili were sometimes found around the cells. Being physically attached on a

158 GCE, the thickness of MR-1 layer is at least the same as the monolayer of MR-1 cells, i.e., 400 times much

159 larger than $1 \mathrm{~nm}$. Moreover, after GCE was coated with Nafion, both anodic and cathodic peak current decreased

160 to the same degree (Fig. S1). The possible reason is that Nafion can prevent anion $\left(\left[\mathrm{Fe}(\mathrm{CN})_{6}\right]^{4-}\right)$ to reach the

161 electrode surface and slow the electrochemical reaction. The MR-1 cells high-efficiently relay the electrons from

$162\left[\mathrm{Fe}(\mathrm{CN})_{6}\right]^{4-}$ to the electrode comparing to 6-Mercaptohexanoic acid. The enhanced electron transfer is

163 responsible for the augmented anodic peak current (Fig. 1 right). Therefore, the asymmetric pattern on

164 voltammetry suggests the electrocatalytic oxidation of $\left[\mathrm{Fe}(\mathrm{CN})_{6}\right]^{4-}$ by $\mathrm{MR}-1$. 

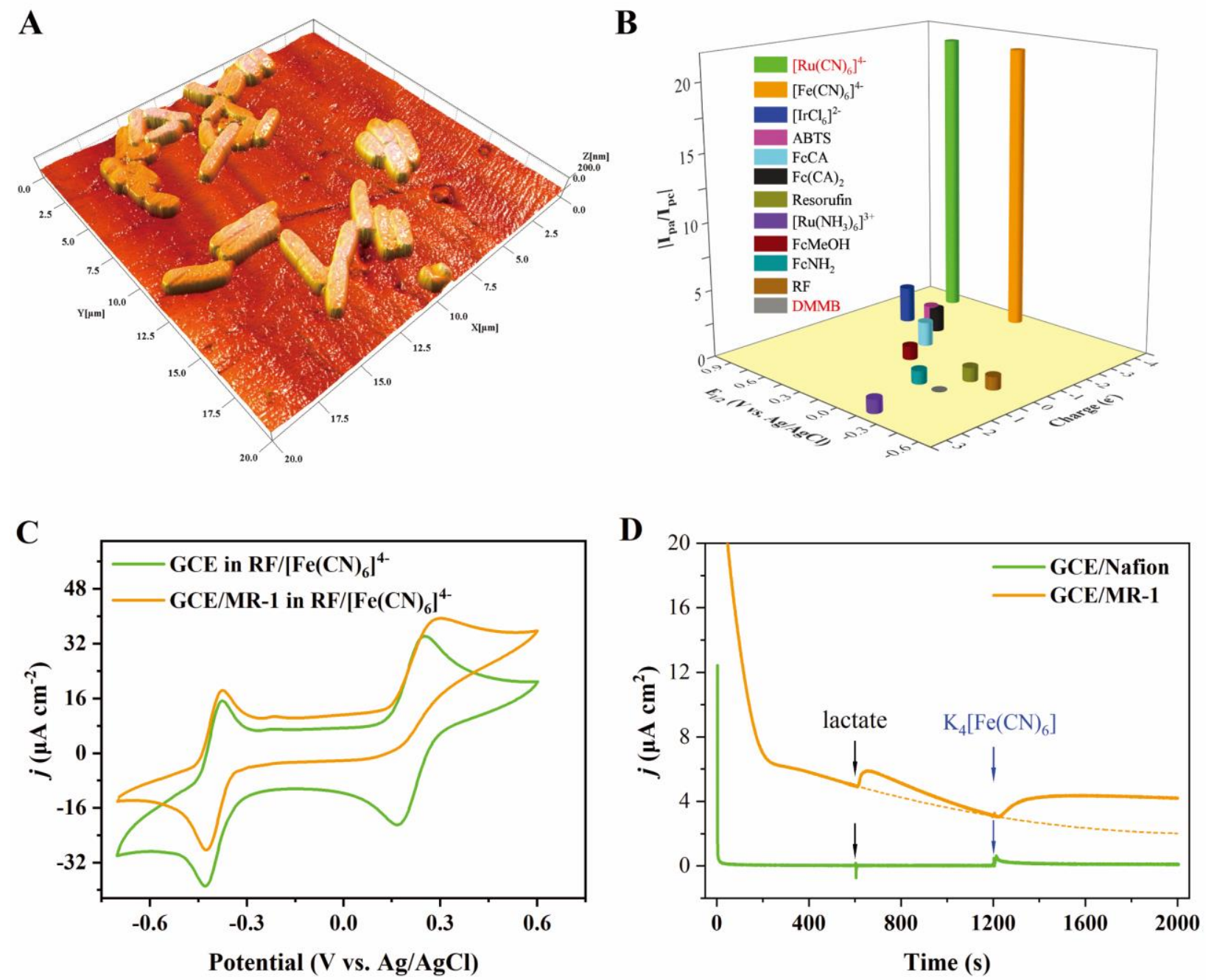

166 Fig. 2. AFM mapping and electrochemical investigation of MR-1. (A) 3D AFM image of MR-1 cluster on a

167 platinum sheet, with sub-monolayer to visualize individual cells. (B) Effects of midpoint potential (E $1 / 2)$ and

168 overall charge(s) of redox molecules on the ratio of anodic peak current to cathodic peak current on GCE/MR-1

$169\left(\left|\mathrm{I}_{\mathrm{pa}} / \mathrm{I}_{\mathrm{ca}}\right|\right)$. ABTS, azino-di-[3-ethylbenzthiazoline sulfonate (6)]; FcCA, ferrocenecarboxylic acid; Fc(CA) $2,1,1^{\prime}-$

170 ferrocenedicarboxylic acid; $\mathrm{RF}$, riboflavin; $\mathrm{FcMeOH}$, hydroxymethylferrocene; $\mathrm{FcNH}_{2}$, aminoferrocene;

171 DMMB, Taylor's Blue. No cathodic peak was observed on GCE/MR-1 in $\left[\mathrm{Ru}(\mathrm{CN})_{6}\right]^{4-}$, so the ratio was set as

172 that of $\left[\mathrm{Fe}(\mathrm{CN})_{6}\right]^{4-}$. Both anodic and cathodic peak disappeared on GCE/MR-1 in DMMB. Voltammetry curves

173 are detailed in Fig. S2. (C) CVs of GCE and GCE/MR-1 in the mixture of $0.25 \mathrm{mM}$ RF and $0.50 \mathrm{mM}$

$174\left[\mathrm{Fe}(\mathrm{CN})_{6}\right]^{4-}\left(\mathrm{RF} /\left[\mathrm{Fe}(\mathrm{CN})_{6}\right]^{4-}\right)$. Scan rate $10 \mathrm{mV} \mathrm{s}^{-1}, 50 \mathrm{mM}$ PBS (pH 7.0). (D) Chronoamperometric curve of

175 lactate and $\left[\mathrm{Fe}(\mathrm{CN})_{6}\right]^{4-}$ on MR-1 under a potential of $0.33 \mathrm{~V}$. Lactate $(1.07 \mathrm{mmol})$ and $\left[\mathrm{Fe}(\mathrm{CN})_{6}\right]^{4-}\left(10^{-4} \mathrm{mmol}\right)$

176 were added to $10 \mathrm{~mL}$ PBS (50 mM, pH 7.0) respectively. The orange dot line is a fitting baseline. 
The voltammetric pattern was further detailed. When MR-1 cells were coated on a GCE, the anodic peak for the oxidation of $\left[\mathrm{Fe}(\mathrm{CN})_{6}\right]^{4-}$ to $\left[\mathrm{Fe}(\mathrm{CN})_{6}\right]^{3-}$ almost sustained at the same level on a bare GCE; while the cathodic peak significantly shrunk for the reduction of $\left[\mathrm{Fe}(\mathrm{CN})_{6}\right]^{3-}$ to $\left[\mathrm{Fe}(\mathrm{CN})_{6}\right]^{4-}(\mathrm{Fig}$. S3). Peak-peak potential separation broadened (ideally $59 \mathrm{mV}$ for GCE, and $168 \mathrm{mV}$ for GCE coated with MR-1) due to the electrochemical polarization caused by the layer of MR-1. A CV of Escherichia coli K-12 coated on a GCE was also conducted as a control. Both anodic and cathodic peak currents decreased uniformly, and peak-peak potential separation increased (Fig. S3, blue line). A systemic investigation was conducted on other 11 redox molecules with different midpoint potential and overall charge(s) (Fig. 2B and Fig. S2). Apparently, asymmetric CV patterns were only observed on the redox molecules with high midpoint potentials and negative charge(s) among these molecules.

Among the 12 redox molecules, riboflavin is special because it is a redox mediator secreted by MR-1. Therefore, we further compared the different voltammetric response between $\left[\mathrm{Fe}(\mathrm{CN})_{6}\right]^{4-}$ and riboflavin. $\mathrm{CVs}$ in an electrolyte containing $0.50 \mathrm{mM}\left[\mathrm{Fe}(\mathrm{CN})_{6}\right]^{4-}$ and $0.25 \mathrm{mM}$ riboflavin were measured. As expected, $\mathrm{CV}$ on a bare GCE showed two pairs of highly symmetric peaks in the mixed electrolyte (Fig. 2C). One pair of peaks belongs to $\left[\mathrm{Fe}(\mathrm{CN})_{6}\right]^{4-}(0.253$ and $0.173 \mathrm{~V})$ and the other is attributed to the two-electron transfer of riboflavin (0.380 and -0.426 V, Fig. S4), which agrees with the results in the literature(Cornejo et al. 2015; Marsili et al. 2008; Peng et al. 2010; Wu et al. 2014). In contrast, a pair of asymmetric peaks (0.294 and 0.174 V) and a pair of symmetric peaks $(-0.377$ and $-0.423 \mathrm{~V})$ are found on a GCE/MR-1 (Fig. $2 \mathrm{C})$ for $\left[\mathrm{Fe}(\mathrm{CN})_{6}\right]^{4-}$ and riboflavin, respectively. Moreover, the shifts in peak potential are very slight for riboflavin after the GCE was coated with MR-1: with a maximum of $3 \mathrm{mV}$ positive shift. Whereas a $39 \mathrm{mV}$ positive shift was observed on the anodic peak for $\left[\mathrm{Fe}(\mathrm{CN})_{6}\right]^{4-}(\mathrm{Fig} .2 \mathrm{C})$. These results further support the selectivity of the electrocatalysis of $\left[\mathrm{Fe}(\mathrm{CN})_{6}\right]^{4-}$ by MR-1. Therefore, the high selectively electrocatalytic oxidation of $\left[\mathrm{Fe}(\mathrm{CN})_{6}\right]^{4-}$ by $\mathrm{MR}-1$ is related to the high midpoint potential and negative charges.

Electrocatalysis promotes an oxidation or a reduction process electrochemically by increasing current or reducing overpotential, giving an asymmetric voltammetry (Lee et al. 2017). Catalytic responses of EAB from 
In the current case, the electrocatalysis of $\left[\mathrm{Fe}(\mathrm{CN})_{6}\right]^{4-}$ oxidation manifests a strong anodic peak accomplished

with a weak cathodic peak, compared to other microbes and molecules (Fig. 1 middle and Fig. S3). This process includes both interfacial electron transfer and diffusion of the redox molecule toward the electrode surface. Further investigation reveals that the asymmetry is depended on the scan rate of CV and the concentration of $\left[\mathrm{Fe}(\mathrm{CN})_{6}\right]^{4-:}$ the asymmetry is apparent with low scan rates and low concentrations (Supplementary Discussion, Fig. S5, and Fig. S6). MR-1 can utilize lactate as an electron donor (Liu et al. 2016; Pinchuk et al. 2009; Tian et al. 2017; Wu et al. 2017), and the corresponding oxidation is reflected by a current increase in chronoamperometry (Fig. 2D). To ensure MR-1 cells immobilized on electrode surface, Nafion was added into the cell layer, which would slightly decrease the catalytic current (Fig. S1). After adding lactate, the current through GCE/MR-1 grew, but not GCE coated with Nafion, suggesting an oxidization of lactate by MR-1 as expected. Furthermore, a much higher current growth was detected through GCE/MR-1 following the addition of

$214\left[\mathrm{Fe}(\mathrm{CN})_{6}\right]^{4-}$, while there was a transient dramatically raise and rapid drop in the current through bare GCE (Fig. 2D). Interestingly, $10^{-4} \mathrm{mmol}\left[\mathrm{Fe}(\mathrm{CN})_{6}\right]^{4-}$ resulted in $1.84 \mu \mathrm{A} \mathrm{cm}{ }^{-2}$ current increase, visibly higher than $1.10 \mu \mathrm{A}$ $\mathrm{cm}^{-2}$ caused by $1.07 \mathrm{mmol}$ lactate. Compared to a four-electron transfer for lactate oxidation (Marsili et al. 2008), $\left[\mathrm{Fe}(\mathrm{CN})_{6}\right]^{4-}$ oxidation is a one-electron transfer. These differences indicate that the presence of $\left[\mathrm{Fe}(\mathrm{CN})_{6}\right]^{4-}$ significantly enhanced the oxidation of $\left[\mathrm{Fe}(\mathrm{CN})_{6}\right]^{4-}$ or lactate, or both.

\subsection{The key factors in $\mathrm{MR}-1$ for $\left[\mathrm{Fe}(\mathrm{CN})_{6}\right]^{4-}$ electrocatalysis were explored}

A number of redox-active compounds have been confirmed to promote the EET of MR-1 (Marsili et al. 2008; Shi et al. 2007; Xiao et al. 2017). To identify the composition in MR-1 causing the electrocatalysis, extracellular polymeric substances (EPS), cytochrome $c$, and riboflavin, which are common redox compounds of MR-1, have been investigated. In the absence and presence of EPS, MR-1 shows similar electrocatalysis pattern, with an anodic peak slightly enhanced for the absence of EPS (Fig. 3A), implying that EPS does not play a crucial role in the electrocatalytic oxidation of $\left[\mathrm{Fe}(\mathrm{CN})_{6}\right]^{4-}$. Small enhancement on the anodic peak could be due to the improved mass transfer causing by the removal of EPS. For the gold electrode modified with 6Mercaptohexanoic acid (6C-HS), no redox peak is found on the $\mathrm{CV}$ in $1 \mathrm{mM}\left[\mathrm{Fe}(\mathrm{CN})_{6}\right]^{4-}$ (Fig. 3B). And a broad and weak peak of $\left[\mathrm{Fe}(\mathrm{CN})_{6}\right]^{4-}$ reduction appeared after the formation of cytochrome $c$ layer (from equine heart) 
on 6C-HS (Fig. 3B). However, the CV of Au/MR-1 show similar pattern as GCE/MR-1 in $1 \mathrm{mM}\left[\mathrm{Fe}(\mathrm{CN})_{6}\right]^{4-}$

230 (Fig. 3B), meaning that MR-1 cells on gold electrode contribute to the electrocatalysis of $\left[\mathrm{Fe}(\mathrm{CN})_{6}\right]^{4-}$ oxidation.

231 Additionally, GCE coated with riboflavin does not change the electrochemical behavior of GCE in $\left[\mathrm{Fe}(\mathrm{CN})_{6}\right]^{4-}$

232 solution, inferred from the reversible voltammetric peaks belonging to riboflavin and $\left[\mathrm{Fe}(\mathrm{CN})_{6}\right]^{4-}(\mathrm{Fig} .3 \mathrm{C})$. The

233 symmetric peaks state that riboflavin does not influence the electrocatalytic oxidation of $\left[\mathrm{Fe}(\mathrm{CN})_{6}\right]^{4-}$. Therefore,

234 the oxidation of $\left[\mathrm{Fe}(\mathrm{CN})_{6}\right]^{4-}$ by MR-1 differs totally from ferric compounds reduction by dissimilatory metal

235 reduction bacteria, since the reduction is enhanced by redox shuttles such as riboflavin (Kumar et al. 2017;

236 Marsili et al. 2008).

A

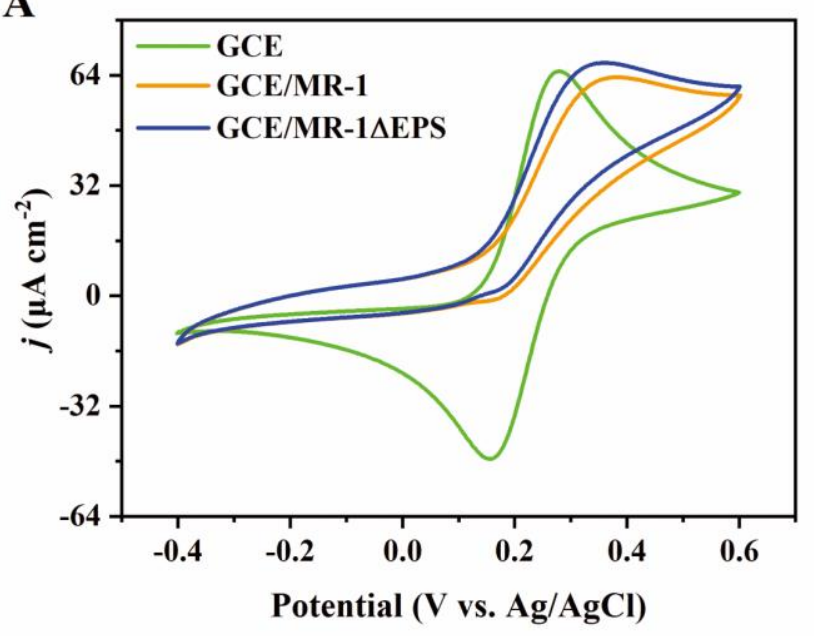

C

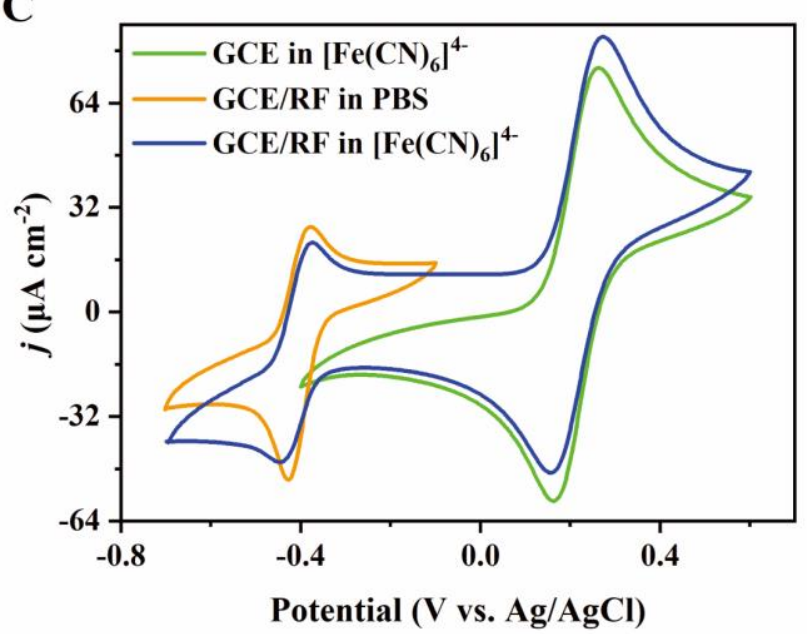

B

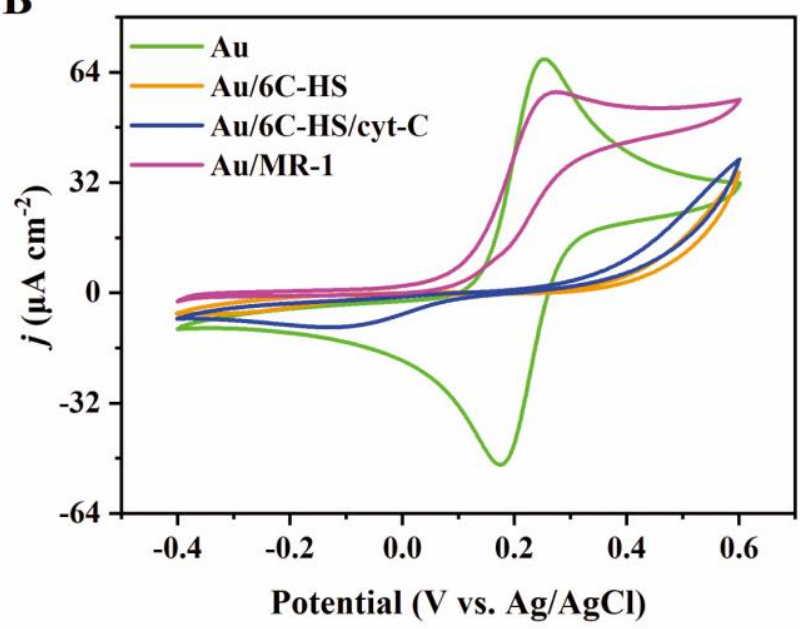

D

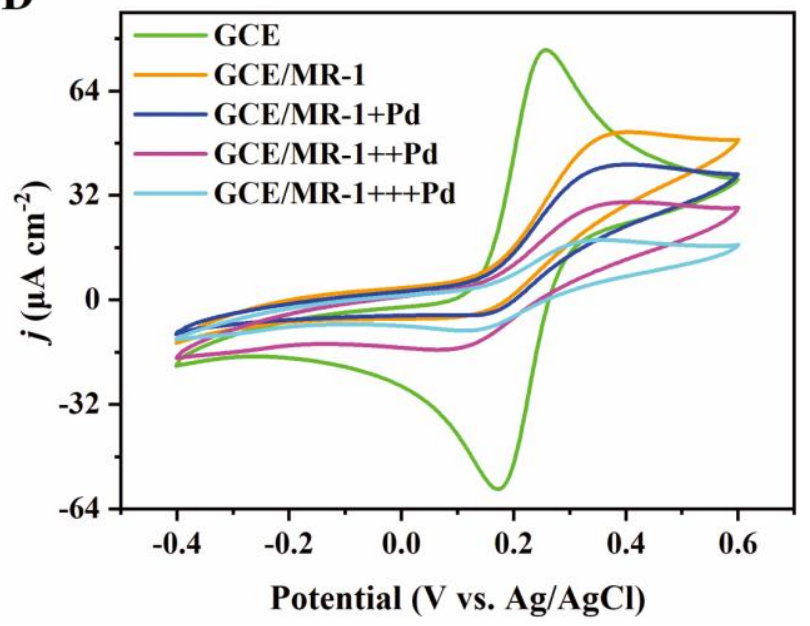

238 Fig. 3. Identification of the composition of MR-1 for the electrocatalysis of $\left[\mathrm{Fe}(\mathrm{CN})_{6}\right]^{4-}$. (A) Cyclic voltammetry (CV) on GCE, GCE/MR-1, GCE coated with MR-1 without EPS (GCE/MR-1 $\triangle \mathrm{EPS})$ in $1.0 \mathrm{mM}\left[\mathrm{Fe}(\mathrm{CN})_{6}\right]^{4-} .(\mathrm{B})$ 
$240 \mathrm{CV}$ on a gold electrode $(\mathrm{Au})$, gold electrode modified with 6-Mercaptohexanoic acid (Au/6C-HS), gold electrode

241 modified with 6-Mercaptohexanoic acid linking cytochrome $c$ from equine heart (Au/6C-HS/cyt-C), and gold

242 electrode modified with MR-1 (Au/MR-1) in $1.0 \mathrm{mM}\left[\mathrm{Fe}(\mathrm{CN})_{6}\right]^{4-}$. (C) $\mathrm{CV}$ on $\mathrm{GCE}$ in $1.0 \mathrm{mM}\left[\mathrm{Fe}(\mathrm{CN})_{6}\right]^{4-}, \mathrm{GCE}$

243 coated with riboflavin $(\mathrm{GCE} / \mathrm{RF})$ in $\mathrm{PBS}$ and $1.0 \mathrm{mM}\left[\mathrm{Fe}(\mathrm{CN})_{6}\right]^{4-}$. (D) $\mathrm{CV}$ of $1.0 \mathrm{mM}\left[\mathrm{Fe}(\mathrm{CN})_{6}\right]^{4-}$ on $\mathrm{GCE}$,

244 GCE/MR-1, GCE coated with MR-1 cultured in M9 medium with $\left[\mathrm{PdCl}_{4}\right]^{2-} .0 .08 \mathrm{mM}(\mathrm{MR}-1+\mathrm{Pd}), 0.40 \mathrm{mM}$

245 (MR-1++Pd), and $0.80 \mathrm{mM}(\mathrm{MR}-1+++\mathrm{Pd})\left[\mathrm{PdCl}_{4}\right]^{2-}$ were used. The electrolyte for CVs $50 \mathrm{mM}$ PBS (pH 7.0)

246 and the scan rate $10 \mathrm{mV} \mathrm{s}^{-1}$.

247 3.3. The formation of palladium nanoparticles on $\mathrm{MR}-1$ block the $\left[\mathrm{Fe}(\mathrm{CN})_{6}\right]^{4-}$ electrocatalytic oxidation

248 As a dissimilatory metal reduction bacterium, MR-1 is able to reduce various metals, for example, Au(III)

249 ions (Wu et al. 2013), Pd(II) ions (Windt et al. 2005; Wu et al. 2018), Ag(I) ions (Suresh et al. 2010), forming

250 corresponding nanoparticles on the surface of MR-1 cells. Some noble metal nanoparticles (for example, Au and

251 Pd nanoparticles) assist EET and catalytically oxidize fuel molecules (Wu et al. 2013; Wu et al. 2018; Wu et al.

252 2010). Surprisingly, the presence of Pd nanoparticles on MR-1 weakened the anodic peak of $\left[\mathrm{Fe}(\mathrm{CN})_{6}\right]^{4-}$

253 systemically (Fig. 3D). Such an effect is much clearer on MR-1 cultured in medium containing a higher

254 concentration of $\left[\mathrm{PdCl}_{4}\right]^{2-}$. Obviously, Pd nanoparticles on MR-1 weakened the oxidation of $\left[\mathrm{Fe}(\mathrm{CN})_{6}\right]^{4-}$. The

255 viability of MR-1 maintained in the presence of $\left[\mathrm{PdCl}_{4}\right]^{2-}$ in the experimental concentration (Wu et al. 2010).

256 More Pd nanoparticles were formed on the surface of MR-1 with a higher concentration of $\left[\mathrm{PdCl}_{4}\right]^{2-}(\mathrm{Fig} .4$, Fig.

257 S7, and Fig. S8). Pd nanoparticles formation on cells can offer three consequences: (a) blocking the mass

258 transfer between specific sites on MR-1 cell membrane and $\left[\mathrm{Fe}(\mathrm{CN})_{6}\right]^{4-}$ in extracellular milieu; (b) introducing

259 the inherent properties of Pd nanoparticles, including boosting electroconductivity, exhibiting catalysis behavior

260 to specific substances (Liu et al. 2016; Wu et al. 2018; Wu et al. 2010), etc.; (c) increasing the specific surface

261 area of MR-1. 

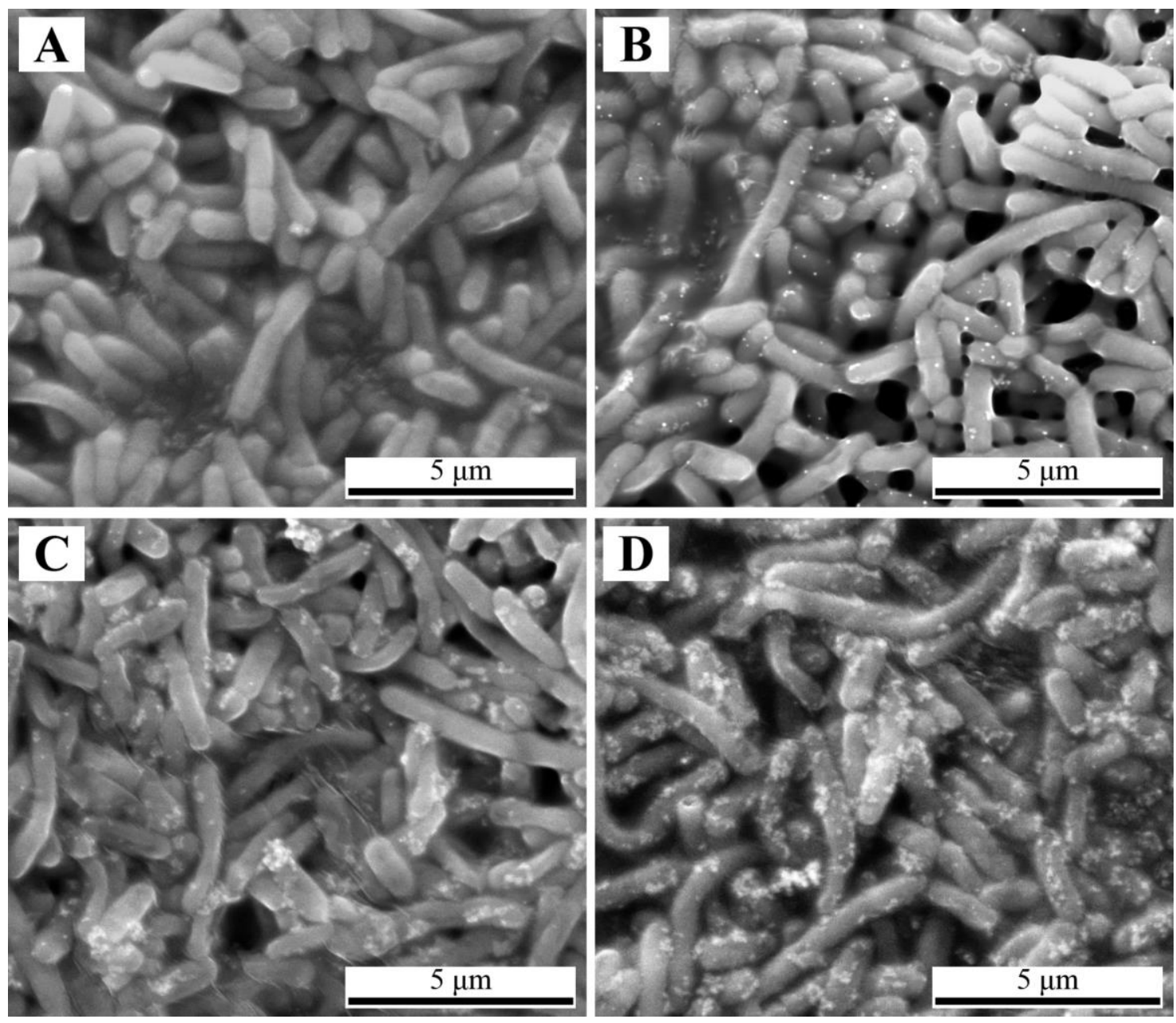

263 Fig. 4. SEM images of MR-1 and MR-1 coated with Pd nanoparticles. MR-1 cultured in M9 medium (A)

264 without $\left[\mathrm{PdCl}_{4}\right]^{2-},(\mathrm{B})$ with $0.08 \mathrm{mM}\left[\mathrm{PdCl}_{4}\right]^{2-}(\mathrm{MR}-1+\mathrm{Pd}),(\mathrm{C})$ with $0.40 \mathrm{mM}\left[\mathrm{PdCl}_{4}\right]^{2-}(\mathrm{MR}-1++\mathrm{Pd}),(\mathrm{D})$ with

$2650.80 \mathrm{mM}\left[\mathrm{PdCl}_{4}\right]^{2-}(\mathrm{MR}-1+++\mathrm{Pd})$. The white dots are Pd nanoparticles.

266 To investigate the influence of inherent properties and the change of specific surface area of Pd nanoparticles

267 on the catalysis of $\left[\mathrm{Fe}(\mathrm{CN})_{6}\right]^{4-}$ oxidation, $\mathrm{Pd}$ nanoparticles were electrodeposited on a $\mathrm{GCE}$ and corresponding

268 voltammetry experiments were conducted (Fig. S9A). The increasing amount of Pd nanoparticles is reflected by

269 enhancing anodic and cathodic peaks on GCE modified with Pd nanoparticles (Fig. S9A), which are caused by

270 the adsorption of hydrogen and oxygen, and corresponding desorption (Allen and Larry 2001). As shown in

271 SEM and EDS, different sizes and amount of Pd nanoparticles on GCE, consequently varied electrode specific

272 surface area, were further confirmed (Fig. S10). However, both the anodic and cathodic peak of $\left[\mathrm{Fe}(\mathrm{CN})_{6}\right]^{4-}$

273 slightly decreased to an almost same extent for all Pd nanoparticles modified GCE (Fig. S9B). These results 
exclude the influence of inherent properties of Pd nanoparticles and the change of specific surface area. Clearly, the presence of Pd nanoparticles on MR-1 blocked the electrocatalysis sites on MR-1.

The cytochromes $c$ play an important role in EET, and they are also possibly responsible for the formation of Pd nanoparticles (Windt et al. 2005). The cytochromes $c$ MtrC and OmcA on MR-1 cells membrane are implicated in the EET process (Shi et al. 2007; Wu et al. 2013). To explore the role of MtrC and OmcA, a

Shewanella oneidensis MR-1 $\Delta o m c A / m t r C$ mutant (MR-1 mutant) was studied under the same experimental conditions. Similarly, an electrocatalysis phenomenon is observed on the MR-1 mutant with the same irreversible CV pattern (Fig. 5A), implying the less effect of MtrC and OmcA, which is contrast to Fe(III) reduction by this mutant (Okamoto et al. 2011). Therefore, the function of other active sites can possibly contribute to the electrocatalysis. Moreover, to study the role of the metabolism of MR-1 in the electrocatalysis, inactive MR-1 cells were prepared by repeatedly freezing with liquid nitrogen with maintaining most of proteins. As shown in the growth curves, the inactive MR-1 cells were unable to breed up to $96 \mathrm{~h}$ (Fig. S11), demonstrating a total inhibition of metabolic activities. The main cell membrane of inactive MR-1 was retained, regardless of some deformation (Fig. S12). Interestingly, the inactive MR-1 caused an asymmetric pair of peaks on $\mathrm{CV}$ in $\left[\mathrm{Fe}(\mathrm{CN})_{6}\right]^{4-}$ solution (Fig. $5 \mathrm{~B}$ ) with a strong anodic peak, indicating the maintaining of the electrocatalysis to $\left[\mathrm{Fe}(\mathrm{CN})_{6}\right]^{4-}$.
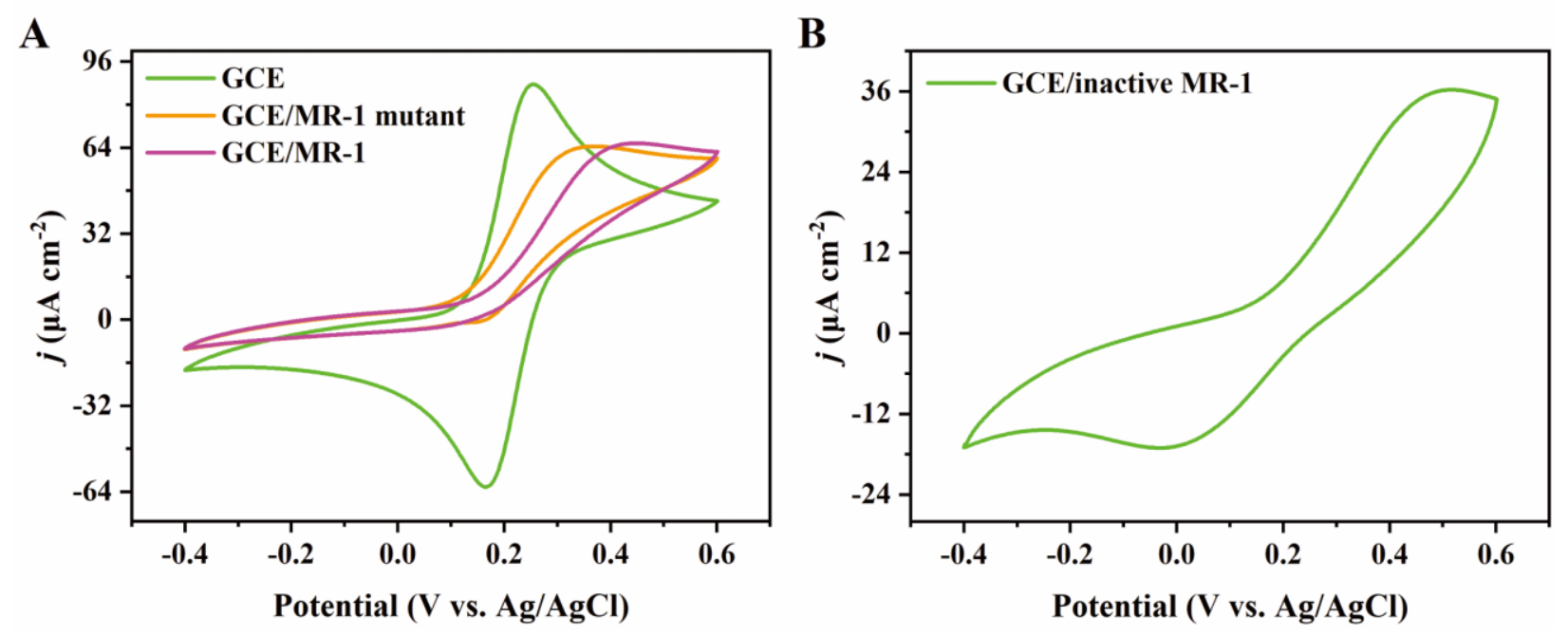
291 Fig. 5. The effect of OmcA, MtrC, and the metabolism of MR-1 on $\left[\mathrm{Fe}(\mathrm{CN})_{6}\right]^{4-}$ oxidation. CV on (A) MR-1

$292 \Delta o m c A / m t r C$ mutant (MR-1 mutant) and (B) repeatedly frozen MR-1 (inactive MR-1) in $1.0 \mathrm{mM}\left[\mathrm{Fe}(\mathrm{CN})_{6}\right]^{4-}$.

293 The electrolyte $50 \mathrm{mM}$ PBS (pH 7.0) and the scan rate $10 \mathrm{mV} \mathrm{s}^{-1}$.

\subsection{The mediating effect of $\left[\mathrm{Fe}(\mathrm{CN})_{6}\right]^{4-3-}$ without extracellular electron donors is limited}

$\left[\mathrm{Fe}(\mathrm{CN})_{6}\right]^{4-3-}$ can act as a redox mediator in some bioelectrochemical process due to high reversibility (Li et al. 2017; Li et al. 2018), like an endogenous redox mediator riboflavin secreted by Shewanella (Marsili et al. 2008).

However, the mediating effect of $\left[\mathrm{Fe}(\mathrm{CN})_{6}\right]^{4-/ 3-}$ alone in non-turnover (without external electron donors) conditions is hard to explain the electrocatalysis.

In the mediating model, $\left[\mathrm{Fe}(\mathrm{CN})_{6}\right]^{4-13-}$ shuttle between the electrode surface and the surface of $\mathrm{EAB}$. The model seems applicable to the current experiments since the MR-1 layer is not impenetrable and a limited amount of $\left[\mathrm{Fe}(\mathrm{CN})_{6}\right]^{4-}$ may penetrate the cell layers and reach to the confined electrode surface that was not occupied by MR-1 cells. When limited amount of $\left[\mathrm{Fe}(\mathrm{CN})_{6}\right]^{4-/ 3-}$ are confined to the small space between the cell layer and the electrode, $\left[\mathrm{Fe}(\mathrm{CN})_{6}\right]^{3-}$ is reduced to $\left[\mathrm{Fe}(\mathrm{CN})_{6}\right]^{4-}$ on the interface between the electrolyte and the $\mathrm{EAB}$ after taking electrons from the $\mathrm{EAB}$, and $\left[\mathrm{Fe}(\mathrm{CN})_{6}\right]^{4-}$ is oxidized to $\left[\mathrm{Fe}(\mathrm{CN})_{6}\right]^{3-}$ on the interface between the electrolyte and the electrode after releasing electrons to the electrode (Fig. S13A). In this case, $\left[\mathrm{Fe}(\mathrm{CN})_{6}\right]^{4-}$ tends to accumulate and an asymmetric CV with strong anodic peak and weak cathodic peak appear on condition that the electron transfer from $\left[\mathrm{Fe}(\mathrm{CN})_{6}\right]^{3-}$ reduction by the EAB continuously outperform that from $\left[\mathrm{Fe}(\mathrm{CN})_{6}\right]^{4-}$ oxidation by electrode during the whole scan (e.g., in a $\mathrm{CV}$ with low scan rate). Furthermore, the electrons relayed by $\left[\mathrm{Fe}(\mathrm{CN})_{6}\right]^{4-3-}$ are ultimately from the metabolism of $\mathrm{EAB}$, for example, the oxidation of acetate or lactate.

On the other hand, different $\mathrm{CVs}$ will be observed if $\left[\mathrm{Fe}(\mathrm{CN})_{6}\right]^{4-/ 3-}$ can diffuse to the bulk electrolyte freely, or the distance between the electrode surface and EAB layer is long, or the voltammetric scan is fast. The $\left[\mathrm{Fe}(\mathrm{CN})_{6}\right]^{4-}$ reduced by MR-1 can diffuse to bulk electrolyte and unlikely get back to the electrode and be oxidized by the electrode. Similarly, the $\left[\mathrm{Fe}(\mathrm{CN})_{6}\right]^{3-}$ oxidized by the electrode can spread into the electrolyte solution and MR-1 is difficult to capture and reduce the $\left[\mathrm{Fe}(\mathrm{CN})_{6}\right]^{3-}$. Moreover, the $\left[\mathrm{Fe}(\mathrm{CN})_{6}\right]^{3-}$ from bulk electrolyte can further dilute the mediating effect of $\left[\mathrm{Fe}(\mathrm{CN})_{6}\right]^{4-/ 3-}$. Therefore, symmetric $\mathrm{CV}$ shape would 
317 present in this situation. For example, when a polyviologen modified glassy carbon electrode (PV-GCE) was 318 used to separate microbes from the electrode surface ( $\mathrm{Li}$ et al. 2017), microbes including EAB colonizing on the 319 PV layer need to employ mediators $\left[\mathrm{Fe}(\mathrm{CN})_{6}\right]^{3-}$ to communicate with the electrode (Fig. S13A). However, the 320 mediating $\left[\mathrm{Fe}(\mathrm{CN})_{6}\right]^{4-/ 3-}$ can freely diffuse to bulk electrolyte, therefore, one symmetric $\mathrm{CV}$ was observed (Li et 321 al. 2017). A similar experiment was conducted with $\mathrm{CV}$ in $1 \mathrm{mM}\left[\mathrm{Fe}(\mathrm{CN})_{6}\right]^{3-}$ and $9 \mathrm{mM}$ glucose at $50 \mathrm{mV} \mathrm{s}^{-1}$, 322 but $\left[\mathrm{Fe}(\mathrm{CN})_{6}\right]^{4-/ 3-}$ were imprisoned in the small space between MR-1 layer and the electrode surface. Although 323 MR-1 is unable to use glucose as an electron donor (Rodionov et al. 2010), the addition of glucose aims to get a 324 full comparison. Differently, the CV became asymmetrical when MR-1 cells were attached on an electrode in 325 solution containing $1 \mathrm{mM}\left[\mathrm{Fe}(\mathrm{CN})_{6}\right]^{3-}$ and $9 \mathrm{mM}$ glucose at $50 \mathrm{mV} \mathrm{s}^{-1}$ (Fig. S14). The different $\mathrm{CV}$ shapes in 326 mediating models may originate from the varied freedom to diffuse and the size of confinement of $\left[\mathrm{Fe}(\mathrm{CN})_{6}\right]^{4-/ 3-}$.

327 In another study, diaphorase molecules, which catalyze the oxidation of nicotinamide adenine dinucleotide 328 (NADH), were absorbed by a PV layer on GCE. The PV layer can accumulate or "trap" $\left[\mathrm{Fe}(\mathrm{CN})_{6}\right]^{4-/ 3-}$. An 329 asymmetric CV, similar to the ones in the current experiment, appeared when the PV-GCE is immersed in a 330 mixed electrolyte containing $\left[\mathrm{Fe}(\mathrm{CN})_{6}\right]^{4-}$, diaphorase, and NADH (Chang et al. 1991). Electrons were captured 331 from NADH by diaphorase, from which the electrons were shuttled by $\left[\mathrm{Fe}(\mathrm{CN})_{6}\right]^{4-/ 3-}$ to the electrode.

332 Consequently, a strong anodic peak and weak cathodic peak displayed, and the anodic peak from NADH 333 oxidation vanished because $\left[\mathrm{Fe}(\mathrm{CN})_{6}\right]^{4-/ 3-}$, rather than $\mathrm{NADH}$, interact with the electrode. Additionally, sufficient 334 electron donor NADH (1 mM) guaranteed a steady catalytic CV curve. confined in a small space between the EAB layer and electrode surface, and abundant subtracts are provided, and the $\mathrm{CV}$ scan rate is relatively low. In contrast, $\mathrm{CV}$ is symmetric if $\left[\mathrm{Fe}(\mathrm{CN})_{6}\right]^{4-3-}$ can spread into bulk electrolyte freely, or the confined space is large, or the scan rate is high. In the current experiment, the asymmetric CV pattern is unchanged from the second to the sixth scan of CV (Fig. S15). The anodic peak current in the first scan was lower than the rest scans due to partial oxidation of $\left[\mathrm{Fe}(\mathrm{CN})_{6}\right]^{4-}$ by oxygen in the air during preparation. The CVs were conducted in non-turnover conditions, i.e., without substrates, therefore, the anodic current would 
shrink as the amount of electrons decreased due to the consumption of stored substrate (if there is any), which is in contrast to the current experimental results (Fig. 3A, Fig. S1, and Fig. S15).

$$
\text { Moreover, Pd nanoparticles can participate in the electron transfer process of Desulfovibrio desulfuricans (Wu }
$$
et al. 2010), and a similar function of Au nanoparticles was also found in MR-1 $\triangle o m c A / m t r C$ mutant (Wu et al. 2013). Therefore, an anodic current increase, at least not a decrease, would be expected when Pd nanoparticles were modified on MR-1, which is different from the observation that the anodic current decreased as the increasing loading of Pd nanoparticles (Fig. 3D). In addition, since RF is an endogenic redox mediator utilized by MR-1, an asymmetric CV would be obtained for RF if the mediating model can lead to electrocatalysis, which does not match the result in Fig. 2C. Furthermore, the electrocatalysis remained after the MR-1 cells were deactivated. The metabolism activity of the cells is the premise of the mediating effect. However, MR-1 cells exhibited electrocatalysis even they were unable to multiply (Fig. 5B).

\subsection{The direct EET between MR-1 and the electrode is feeble}

An electrocatalysis model was also considered, in which MR-1 could oxidize $\left[\mathrm{Fe}(\mathrm{CN})_{6}\right]^{4-}$ and capture electrons on the interface of the electrolyte and the cell surface, and the electrons are transported to electrode through the interface between cell surface and the electrode coupling with the oxidation of some redox molecules (e.g., cytochromes $c$ ) on the cell membrane (Fig. S13B). This model is justified by the fact that adequate MR-1 cells are attached on the electrode surface. The electrochemical signals of redox proteins in the outer membrane of MR-1 were detected in voltammetry (Fig. S16). Redox pair with the peak potentials $-0.435 \mathrm{~V}$ (anodic) and $0.415 \mathrm{~V}$ (cathodic) are attributed to flavins (Marsili et al. 2008; Okamoto et al. 2013; Xiao et al. 2017), whereas the pairs at -0.137 as well as $0.065 \mathrm{~V}$ (anodic) and -0.124 as well as $0.113 \mathrm{~V}$ (cathodic) are attributed to outer membrane cytochromes $c$ (Carmona-Martinez et al. 2011; Okamoto et al. 2013; Xiao et al. 2017). Similar electrochemical signals were obtained from previous reports via this physically attaching method (Tian et al. 2017; Wu et al. 2013; Wu et al. 2015; Wu et al. 2014; Wu et al. 2010; Xiao et al. 2017). These results strongly support that sufficient MR-1 cells are directly contacting instead of far away from the surface of the electrode. In the electrocatalysis model, the electrons are from the oxidation of abundant $\left[\mathrm{Fe}(\mathrm{CN})_{6}\right]^{4-}$ instead of MR-1 cells, therefore, the anodic current remained at a comparable level with bare electrodes. 
However, the electrocatalysis model hardly elucidate the shift of midpoint potentials when different redox molecules were used in electrolytes (Fig. S2). During the forward scan of the CVs (from low potential to high potential), the electrode directly oxidized the redox molecules on cell membrane regardless of which reactant in electrolyte. Thus, the midpoint potential in CVs is related to the redox molecules on cell membrane, not the reactant in the electrolyte. For example, the peaks of cytochromes $c$ on Geobacter sulfurreducens, instead of the peak of acetate, were enhanced when Geobacter sulfurreducens catalyzed the oxidation of acetate (Richter et al. 2009). By contrast, the peak belonging to cytochromes $c$ at around $-0.1 \mathrm{~V}$ disappeared when $\left[\mathrm{Fe}(\mathrm{CN})_{6}\right]^{4-}$ was introduced (Fig. S17). The peak of cytochromes $c$ should be enhanced if electrons were transported directly from cytochromes $c$ to the electrode.

Therefore, the direct EET between MR-1 and the electrode is weak, and the strong electron transfer in the forward scan (i.e., anodic current) must be accomplished through another EET pathway. A plausible model combining electrocatalysis and mediating model is proposed in Fig. 6 and will be discussed in the Discussion part.

\section{Discussion}

We here have found the intake of electrons from $\left[\mathrm{Fe}(\mathrm{CN})_{6}\right]^{4-}$ by MR-1, presenting an irreversible pattern on voltammetry. The discovery of the ability for MR-1 to take electrons from $\left[\mathrm{Fe}(\mathrm{CN})_{6}\right]^{4-}$ broadens our knowledge about the role of dissimilatory metal reduction bacteria in BESs. MR-1 promotes only anodic current and blocks cathodic current during $\left[\mathrm{Fe}(\mathrm{CN})_{6}\right]^{4-/ 3-}$ cycling. This electrocatalysis is in contrast to E. coli $\mathrm{K}-12$ and Streptococcus mutans (Hu et al. 2010), in which both cathodic and anodic peaks shrunk equally in CV. So far, we only find that MR-1 electrocatalyzes the oxidation of negatively charged redox molecules with high midpoint potentials. Hence, other bacteria do not catalyze the oxidation of $\left[\mathrm{Fe}(\mathrm{CN})_{6}\right]^{4-}$ to $\left[\mathrm{Fe}(\mathrm{CN})_{6}\right]^{3-}$, but the increase barrier for interfacial electron transfer. These results also exclude the effect of the negative charges on electrode surfaces causing "electrochemical rectification" with an asymmetric voltammetry shape for a redox couple (Chi et al. 2006), because MR-1, E.coli K-12, and Streptococcus mutans are all negatively charged in a neutral medium (Silhavy et al. 2010). The recurrence of irreversible voltammetry pattern on other negatively charged 
redox molecules with high midpoint potentials implies the connection between the electrocatalysis and redox potential as well as overall charge(s). not open until protein secretion (Reichow et al. 2010). The size of hydrated $\left[\mathrm{Fe}(\mathrm{CN})_{6}\right]^{4-}$ is at least $1.2 \mathrm{~nm}$ in diameter (Prampolini et al. 2014), and it is hard for $\left[\mathrm{Fe}(\mathrm{CN})_{6}\right]^{4-}$ to penetrate lipid bilayer of the cell membrane (Koley and Bard 2010). However, the $\left[\mathrm{Fe}(\mathrm{CN})_{6}\right]^{4-}$ can effectively diffuse to the outer membrane due to its high solubility. Additionally, the presence or absence of EPS on MR-1 make no difference in $\left[\mathrm{Fe}(\mathrm{CN})_{6}\right]^{4-}$ oxidation, while EPS plays a crucial role in the outward EET of MR-1 (Xiao et al. 2017).

Very excitingly, Pd nanoparticles on MR-1 are found to blocked $\left[\mathrm{Fe}(\mathrm{CN})_{6}\right]^{4-}$ oxidation catalyzed by the cells. cytochromes $c$ influence or participate in the electrocatalytic oxidation. On the other hand, cytochrome $c \operatorname{MtrC}$ and $\mathrm{OmcA}$ do not catalyze $\left[\mathrm{Fe}(\mathrm{CN})_{6}\right]^{4-}$ oxidation. $\mathrm{MtrC}$ and $\mathrm{OmcA}$ are crucial to the reduction of various insoluble electron acceptors (Shi et al. 2007; Wu et al. 2013). Considering the unique electrocatalysis of $\left[\mathrm{Fe}(\mathrm{CN})_{6}\right]^{4-}$ oxidation, we believe the existence of active sites on MR-1, which are responsible for the catalysis. We have not identified the composition of these active sites yet, but we hypothesize that they could be small, macro molecules even proteins, such as high-redox potential cytochromes $c$, laccases, or peroxidase. They are adjacent to active sites of $\left[\mathrm{PdCl}_{4}\right]^{2-}$ reduction and contribute to the electrocatalysis of $\left[\mathrm{Fe}(\mathrm{CN})_{6}\right]^{4-}$ oxidation. These active sites may also be responsible for the $\mathrm{Mn}$ (II) oxidation as mentioned in the introduction part. For iron respiratory, there are two possible pathways, i.e., downhill pathway and uphill pathway. The downhill pathway produces energy, in which the electrons from iron oxidizing are terminally transferred to oxygen reduction. The uphill pathway is related to protonmotive force, in which electrons are transported against the unfavorable redox potential and finally reach to $\mathrm{NAD}(\mathrm{P})^{+}($Bird et al. 2011). Thus, the cytochromes $c$ cannot be

416 excluded completely. Furthermore, MR-1 is capable of oxidizing $\left[\mathrm{Fe}(\mathrm{CN})_{6}\right]^{4-}$ after repeating freezing. In this 
respiration of MR-1, dominate the catalysis of $\left[\mathrm{Fe}(\mathrm{CN})_{6}\right]^{4-}$, which further differ from the reduction of insoluble $419 \mathrm{Fe}(\mathrm{III}) / \mathrm{Mn}(\mathrm{IV})$ oxides.

420 A plausible model with inward EET and outward EET is proposed for $\left[\mathrm{Fe}(\mathrm{CN})_{6}\right]^{4-}$ oxidation electrocatalyzed 421 by MR-1 (Fig. 6). [ $\left.\mathrm{Fe}(\mathrm{CN})_{6}\right]^{4-}$ can diffuse into the space between MR-1 layer and the electrode or adsorb on the 422 surface of the MR-1 cells, as well as stay in the bulk electrolyte. In fact, $\left[\mathrm{Fe}(\mathrm{CN})_{6}\right]^{4-}$ play two roles in the model.

423 Firstly, electrons from $\left[\mathrm{Fe}(\mathrm{CN})_{6}\right]^{4-}$ are transferred into the MR-1 cells where the active sites on the cell 424 membrane oxidize $\left[\mathrm{Fe}(\mathrm{CN})_{6}\right]^{4-}$ to $\left[\mathrm{Fe}(\mathrm{CN})_{6}\right]^{3-}$. This is an inward EET process (Fig. 6B). Secondly, the obtained 425 electrons can be transferred to the electrode by two forms of outward EET. It has been reported that mediated 426 EET is the main outward EET strategy of MR-1, contributing more than 70\% current of outward EET (Marsili et 427 al. 2008). Therefore, a small fraction of electrons may be transferred to the electrode via the direct EET form, 428 but the majority of electrons would be transferred by the indirect EET mediated by $\left[\mathrm{Fe}(\mathrm{CN})_{6}\right]^{4-3-}$. The mediating 429 effect of $\left[\mathrm{Fe}(\mathrm{CN})_{6}\right]^{4-/ 3-}$ are both valid in the complete MtrCAB pathway and the incomplete MtrCAB pathway. In 430 the complete MtrCAB pathway, the electrons are delivered from CymA to MtrA, where MtrA and MtrB relay 431 the electrons to $\mathrm{MtrC}$ and $\mathrm{OmcA}$, and electrons were finally received by $\left[\mathrm{Fe}(\mathrm{CN})_{6}\right]^{3-}$. In the incomplete $\mathrm{MtrCAB}$ 432 pathway, the MtrC and OmcA are removed. Nonetheless, MtrA fully inserts into MtrB (Edwards et al. 2018), 433 and $\left[\mathrm{Fe}(\mathrm{CN})_{6}\right]^{3-}$ may therefore execute outward EET by directly accepting electrons from the MtrA (Fig. 6C).

434 The exact route for the electron transfer from the active sites on the cell membrane (red dotted circle in Fig. 6) to 435 the sites where $\left[\mathrm{Fe}(\mathrm{CN})_{6}\right]^{4-/ 3-}$ mediate EET (blue dotted circle in Fig. 6) is not clear yet and needs further 436 investigation. 


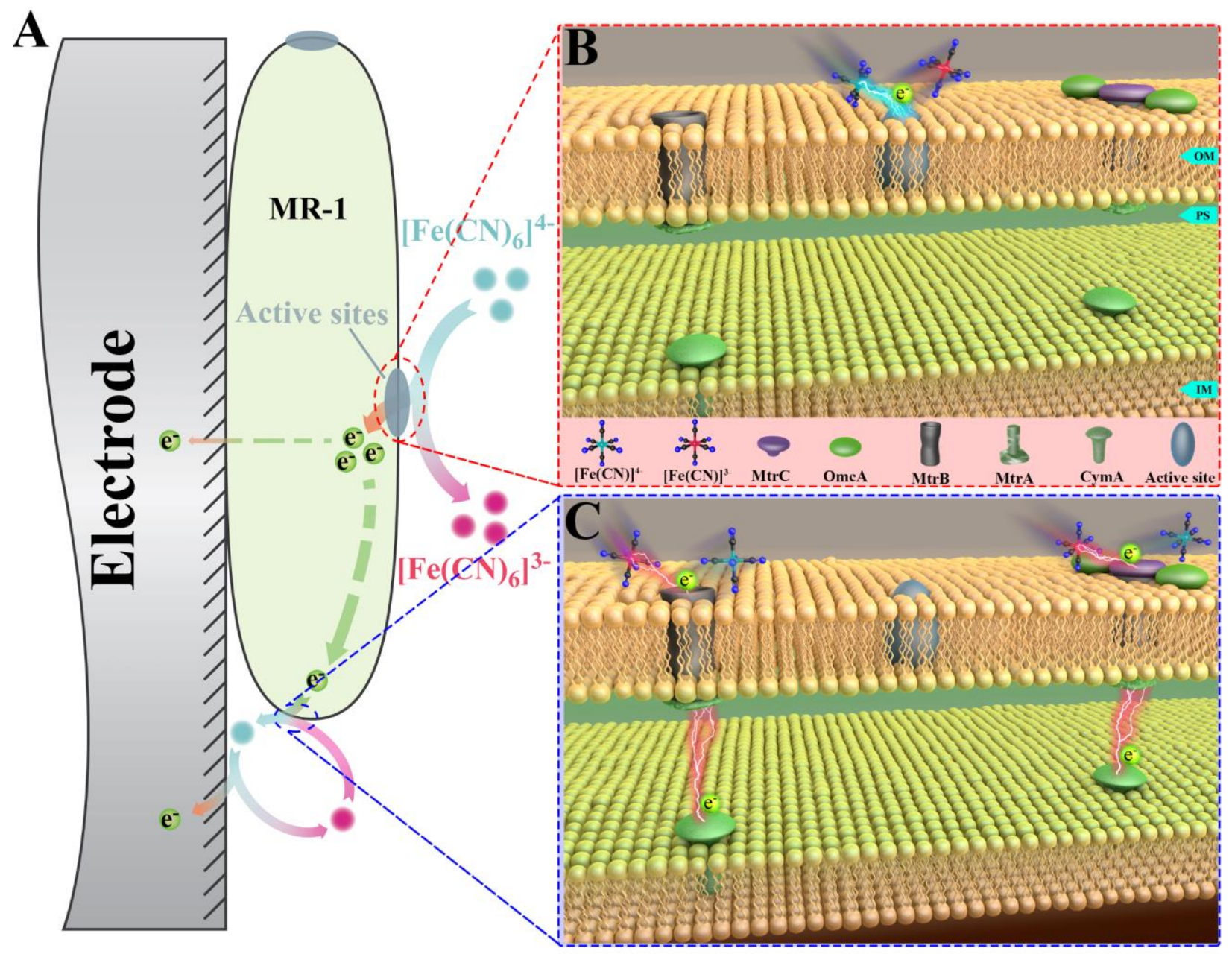

438 Fig. 6. Illustration of electrons uptake by MR-1 from $\left[\mathrm{Fe}(\mathrm{CN})_{6}\right]^{4-}$. (A) The overall process of the inward and 439 outward EET of $\left[\mathrm{Fe}(\mathrm{CN})_{6}\right]^{4-}$ from MR-1 to the electrode. $\left[\mathrm{Fe}(\mathrm{CN})_{6}\right]^{4-}$ are oxidized (red dotted circle) and the 440 obtained electrons are mainly transported by the indirect EET through mediator $\left[\mathrm{Fe}(\mathrm{CN})_{6}\right]^{4-/ 3-}($ blue dotted 441 circle), and the rest of electrons may be transferred via short-distance direct EET by redox molecules on the membrane. The processes indicated by green dotted arrows are not clear yet. Only one MR-1 cell is presented for clarity. (B) Inward EET. In this process, bulk $\left[\mathrm{Fe}(\mathrm{CN})_{6}\right]^{4-}$ in the electrolyte are oxidized by the active sites on MR-1 and electrons are captured. (C) Outward EET. In this process, a small portion of $\left[\mathrm{Fe}(\mathrm{CN})_{6}\right]^{4-}$ diffuse into the narrow confinement between the MR-1 layer and the electrode surface and shuttle the EET process between the cell and the electrode. This mediating process can proceed with or without MtrC and OmcA. Only relevant parts are presented, and the quinone and quinol pool in the cytoplasmic membrane are not shown for simplicity.

448 OM: outer membrane; PS: periplasm; IM: inner membrane. The scale is not proportional. 

active sites instead of the respiration of MR-1 contribute to the electrocatalytic oxidation of $\left[\mathrm{Fe}(\mathrm{CN})_{6}\right]^{4-}$. We reported to be able to oxidize $\mathrm{Mn}$ (II) (Wright et al. 2016), the ability of MR-1 to oxidize iron compounds has not been discovered before. More effort would be spent to study the composition and function of the active sites in future studies.

\section{Conclusion}

MR-1 electrocatalyzes $\left[\mathrm{Fe}(\mathrm{CN})_{6}\right]^{4-}$ oxidation with high efficiency and high selectivity. The selectivity is most slow scan rate and low $\left[\mathrm{Fe}(\mathrm{CN})_{6}\right]^{4-}$ concentration, presenting a noticeable asymmetric voltammetry pattern. $\left[\mathrm{Fe}(\mathrm{CN})_{6}\right]^{4-}$ oxidation is an inward EET process, in which $\left[\mathrm{Fe}(\mathrm{CN})_{6}\right]^{4-}$ donate electrons to MR-1. This oxidation is entirely distinct from the reduction of $\mathrm{Fe}(\mathrm{III}) / \mathrm{Mn}(\mathrm{IV})$ oxides and not affected by riboflavin, EPS and in vitro cytochrome $c$. In contrast, Pd nanoparticles on the cells can block the active sites and undermine the electrocatalysis of $\left[\mathrm{Fe}(\mathrm{CN})_{6}\right]^{4-}$ oxidation by MR-1. A model with the combination of electrocatalysis of $\left[\mathrm{Fe}(\mathrm{CN})_{6}\right]^{4-}$ and the mediating effect of $\left[\mathrm{Fe}(\mathrm{CN})_{6}\right]^{4-3-}$ is therefore proposed. The electrocatalysis of $\left[\mathrm{Fe}(\mathrm{CN})_{6}\right]^{4-}$ involves unidentified active sites. Furthermore, the mediating role of $\left[\mathrm{Fe}(\mathrm{CN})_{6}\right]^{4-/ 3-}$ can be executed with or without MtrC and OmcA. Our experiments indicate strongly that they locate mostly likely in cell membrane with biomolecule properties. The properties of the active sites are different to that of the widely studied substances related with MR-1 (e.g., RF, MtrC, and OmcA). To identify the origin and chemical composition of these active sites on MR-1 is crucial and such investigation requires a comprehensive effort in electrochemistry, microbiology, and nanochemistry. The discovery of unique electrocatalysis of MR-1 towards the oxidation of ferrocyanide provides a better understanding of the role of dissimilatory metal reduction bacteria in BESs and the detection of redox molecules with high midpoint potential and negatively charge(s).

\section{Supporting Information}


Supplementary data to this article can be found online at XXX.

476

477

478

479

480

481

482

483

484

485

486

487

488

489

490

491

492

493

494

495

496

497

498

499

500

501

\section{Acknowledgements}

Financial support from the China Scholarship Council (CSC) (No. 201606130019), Carlsberg foundation (CF150164), Universities Denmark, the National Natural Science Foundation of China $(41471260,51478451)$ and Otto Mønsted foundation is greatly appreciated.

\section{References}

Allen, J.B., Larry, R.F., 2001. Electrochemical methods: fundamentals and applications, 2nd ed. John Wiley \& Sons, Inc.

Bird, L.J., Bonnefoy, V., Newman, D.K., 2011. Trends Microbiol. 19(7), 330-340.

Blöthe, M., Wegorzewski, A., Müller, C., Simon, F., Kuhn, T., Schippers, A., 2015. Environ. Sci. Technol. 49(13), 7692-7700.

Bose, A., Gardel, E.J., Vidoudez, C., Parra, E.A., Girguis, P.R., 2014. Nat. Commun. 5, 3391.

Bräuer, S.L., Adams, C., Kranzler, K., Murphy, D., Xu, M., Zuber, P., Simon, H.M., Baptista, A.M., Tebo, B.M., 2011. Environ. Microbiol. 13(3), 589-603.

Bretschger, O., Obraztsova, A., Sturm, C.A., Chang, I.S., Gorby, Y.A., Reed, S.B., Culley, D.E., Reardon, C.L., Barua, S., Romine, M.F., Zhou, J., Beliaev, A.S., Bouhenni, R., Saffarini, D., Mansfeld, F., Kim, B.-H., Fredrickson, J.K., Nealson, K.H., 2007. Appl. Environ. Microbiol. 73(21), 7003-7012.

Carmona-Martinez, A.A., Harnisch, F., Fitzgerald, L.A., Biffinger, J.C., Ringeisen, B.R., Schröder, U., 2011. Bioelectrochemistry 81(2), 74-80.

Castelle, C., Guiral, M., Malarte, G., Ledgham, F., Leroy, G., Brugna, M., Giudici-Orticoni, M.-T., 2008. J. Biol. Chem. 283(38), 25803-25811.

Chang, H.-C., Osawa, M., Matsue, T., Uchida, I., 1991. J. Chem. Soc., Chem. Commun.(9), 611-612.

Chi, Q., Zhang, J., Andersen, J.E.T., Ulstrup, J., 2001. J. Phys. Chem. B 105(20), 4669-4679.

Chi, Q., Zhang, J., Ulstrup, J., 2006. J. Phys. Chem. B 110(3), 1102-1106.

Coker, V.S., Bennett, J.A., Telling, N.D., Henkel, T., Charnock, J.M., van der Laan, G., Pattrick, R.A.D., Pearce, C.I., Cutting, R.S., Shannon, I.J., Wood, J., Arenholz, E., Lyon, I.C., Lloyd, J.R., 2010. ACS Nano 4(5), 25772584. 
Cornejo, J.A., Lopez, C., Babanova, S., Santoro, C., Artyushkova, K., Ista, L., Schuler, A.J., Atanassov, P., 2015. J. Electrochem. Soc. 162(9), H597-H603.

504 Cruz-García, C., Murray, A.E., Klappenbach, J.A., Stewart, V., Tiedje, J.M., 2007. J. Bacteriol. 189(2), 656$505 \quad 662$.

506 DiChristina, T.J., DeLong, E.F., 1993. Appl. Environ. Microbiol. 59(12), 4152-4160.

507 Edwards, M.J., White, G.F., Lockwood, C.W., Lawes, M.C., Martel, A., Harris, G., Scott, D.J., Richardson, D.J., 508 Butt, J.N., Clarke, T.A., 2018. J. Biol. Chem. 293(21), 8103-8112.

509 El-Naggar, M.Y., Wanger, G., Leung, K.M., Yuzvinsky, T.D., Southam, G., Yang, J., Lau, W.M., Nealson, 510 K.H., Gorby, Y.A., 2010. Proc. Natl. Acad. Sci. U. S. A. 107(42), 18127-18131.

511 Hartshorne, R.S., Reardon, C.L., Ross, D., Nuester, J., Clarke, T.A., Gates, A.J., Mills, P.C., Fredrickson, J.K., 512 Zachara, J.M., Shi, L., Beliaev, A.S., Marshall, M.J., Tien, M., Brantley, S., Butt, J.N., Richardson, D.J., 2009.

513 Proc. Natl. Acad. Sci. U. S. A. 106(52), 22169-22174.

514 Heidelberg, J.F., Paulsen, I.T., Nelson, K.E., Gaidos, E.J., Nelson, W.C., Read, T.D., Eisen, J.A., Seshadri, R., 515 Ward, N., Methe, B., Clayton, R.A., Meyer, T., Tsapin, A., Scott, J., Beanan, M., Brinkac, L., Daugherty, S., 516 DeBoy, R.T., Dodson, R.J., Durkin, A.S., Haft, D.H., Kolonay, J.F., Madupu, R., Peterson, J.D., Umayam, L.A., 517 White, O., Wolf, A.M., Vamathevan, J., Weidman, J., Impraim, M., Lee, K., Berry, K., Lee, C., Mueller, J., 518 Khouri, H., Gill, J., Utterback, T.R., McDonald, L.A., Feldblyum, T.V., Smith, H.O., Venter, J.C., Nealson, 519 K.H., Fraser, C.M., 2002. Nat. Biotechnol. 20, 1118-1123.

520 Höfer, C., Schlosser, D., 1999. FEBS Lett. 451(2), 186-190.

521 Hu, Y., Zhang, J., Ulstrup, J., 2010. Langmuir 26(11), 9094-9103.

522 J.M., M., C.R., M., 2003. Lett. Appl. Microbiol. 37(1), 21-25.

523 Jana, P.S., Katuri, K., Kavanagh, P., Kumar, A., Leech, D., 2014. Phys. Chem. Chem. Phys. 16(19), 9039-9046.

524 Kimber, R.L., Lewis, E.A., Parmeggiani, F., Smith, K., Bagshaw, H., Starborg, T., Joshi, N., Figueroa, A.I., van 525 der Laan, G., Cibin, G., Gianolio, D., Haigh, S.J., Pattrick, R.A.D., Turner, N.J., Lloyd, J.R., 2018. Small 526 14(10), 1703145.

Koley, D., Bard, A.J., 2010. Proceedings of the National Academy of Sciences 107(39), 16783.

528 Kumar, A., Conghaile, P.Ó., Katuri, K., Lens, P., Leech, D., 2013a. RSC Adv. 3(41), 18759-18761.

529 Kumar, A., Hsu, L.H.-H., Kavanagh, P., Barrière, F., Lens, P.N.L., Lapinsonnière, L., Lienhard V, J.H., 530 Schröder, U., Jiang, X., Leech, D., 2017. Nat. Rev. Chem. 1, 0024. 
Kumar, A., Katuri, K., Lens, P., Leech, D., 2012. Biochem. Soc. Trans. 40(6), 1308-1314.

Kumar, A., Siggins, A., Katuri, K., Mahony, T., O’Flaherty, V., Lens, P., Leech, D., 2013b. Chem. Eng. J. 230, 532-536.

534 Lee, K.J., Elgrishi, N., Kandemir, B., Dempsey, J.L., 2017. Nat. Rev. Chem. 1, 0039.

Li, S.-L., Bai, M.-D., Hsiao, C.-J., Cheng, S.-S., Nealson, K.H., 2017. Bioelectrochemistry 118, 147-153.

Li, S.-L., Yen, J.-H., Kano, K., Liu, S.-M., Liu, C.-L., Cheng, S.-S., Chen, H.-Y., 2018. Bioelectrochemistry $124,119-126$.

Liu, J., Zheng, Y., Hong, Z., Cai, K., Zhao, F., Han, H., 2016. Sci. Adv. 2(9), e1600858.

Lovley, D.R., 2012. Annu. Rev. Microbiol. 66(1), 391-409.

Marsili, E., Baron, D.B., Shikhare, I.D., Coursolle, D., Gralnick, J.A., Bond, D.R., 2008. Proc. Natl. Acad. Sci. U. S. A. 105(10), 3968-3973.

Okamoto, A., Hashimoto, K., Nealson, K.H., Nakamura, R., 2013. Proc. Natl. Acad. Sci. U. S. A. 110(19), $543 \quad 7856-7861$.

544 Okamoto, A., Nakamura, R., Hashimoto, K., 2011. Electrochim. Acta 56(16), 5526-5531.

Palma, C., Martínez, A.T., Lema, J.M., Martínez, M.J., 2000. J. Biotechnol. 77(2), 235-245.

546 Peng, L., You, S., Wang, J., 2010. Biosens. Bioelectron. 25(11), 2530-2533.

547 Philips, J., Van den Driessche, N., De Paepe, K., Prévoteau, A., Gralnick, J.A., Arends, J.B.A., Rabaey, K., 548 2018. Appl. Environ. Microbiol. 84(20), e01154-01118.

549 Pinchuk, G.E., Geydebrekht, O.V., Hill, E.A., Reed, J.L., Konopka, A.E., Beliaev, A.S., Fredrickson, J.K., 2011. 550 Appl. Environ. Microbiol. 77(23), 8234-8240.

551 Pinchuk, G.E., Rodionov, D.A., Yang, C., Li, X., Osterman, A.L., Dervyn, E., Geydebrekht, O.V., Reed, S.B., 552 Romine, M.F., Collart, F.R., Scott, J.H., Fredrickson, J.K., Beliaev, A.S., 2009. Proc. Natl. Acad. Sci. U. S. A. 553 106(8), 2874-2879.

554 Piontek, K., Antorini, M., Choinowski, T., 2002. J. Biol. Chem. 277(40), 37663-37669.

Prampolini, G., Yu, P., Pizzanelli, S., Cacelli, I., Yang, F., Zhao, J., Wang, J., 2014. J. Phys. Chem. B 118(51), $556 \quad 14899-14912$.

557 Prévoteau, A., Clauwaert, P., Kerckhof, F.-M., Rabaey, K., 2019. Biosens. Bioelectron. 132, 115-121.

558 Reichow, S.L., Korotkov, K.V., Hol, W.G.J., Gonen, T., 2010. Nat. Struct. Mol. Biol. 17, 1226. 
559

560

561

562

563

564

565

566

567

568

569

570

571

572

573

574

575

576

577

578

579

580

581

582

583

584

585

586

Richter, H., Nevin, K.P., Jia, H., Lowy, D.A., Lovley, D.R., Tender, L.M., 2009. Energy Environ. Sci. 2(5), 506-516.

Rodionov, D.A., Yang, C., Li, X., Rodionova, I.A., Wang, Y., Obraztsova, A.Y., Zagnitko, O.P., Overbeek, R., Romine, M.F., Reed, S., Fredrickson, J.K., Nealson, K.H., Osterman, A.L., 2010. BMC Genomics 11(1), 494.

Ross, D.E., Flynn, J.M., Baron, D.B., Gralnick, J.A., Bond, D.R., 2011. PLoS ONE 6(2), e16649.

Schröder, U., Harnisch, F., 2017. Joule 1(2), 244-252.

Sheetal, S., Samantha, R., Margie, R., Daad, S., 2011. Environ. Microbiol. 13(1), 108-115.

Shi, L., Squier, T.C., Zachara, J.M., Fredrickson, J.K., 2007. Mol. Microbiol. 65(1), 12-20.

Shleev, S.V., Ir Gvon, K., Morozova, O.V., Mazhugo, Y.M., Khalunina, A.S., Yaropolov, A.I., 2004. Appl. Biochem. Microbiol. 40(2), 140-145.

Silhavy, T.J., Kahne, D., Walker, S., 2010. Cold Spring Harb. Perspect. Biol. 2(5), a000414.

Sinirlioglu, Z.A., Sinirlioglu, D., Akbas, F., 2013. Bioresour. Technol. 146, 807-811.

Soldatova, A.V., Butterfield, C., Oyerinde, O.F., Tebo, B.M., Spiro, T.G., 2012. JBIC J. Biol. Inorg. Chem. 17(8), 1151-1158.

Staudigel, H., Hart, S.R., Pile, A., Bailey, B.E., Baker, E.T., Brooke, S., Connelly, D.P., Haucke, L., German, C.R., Hudson, I., Jones, D., Koppers, A.A.P., Konter, J., Lee, R., Pietsch, T.W., Tebo, B.M., Templeton, A.S., Zierenberg, R., Young, C.M., 2006. Proceedings of the National Academy of Sciences 103(17), 6448.

Sun, D.-Z., Yu, Y.-Y., Xie, R.-R., Zhang, C.-L., Yang, Y., Zhai, D.-D., Yang, G., Liu, L., Yong, Y.-C., 2017. Biosens. Bioelectron. 87, 195-202.

Suresh, A.K., Pelletier, D.A., Wang, W., Moon, J.-W., Gu, B., Mortensen, N.P., Allison, D.P., Joy, D.C., Phelps, T.J., Doktycz, M.J., 2010. Environ. Sci. Technol. 44(13), 5210-5215.

Tan, Y., Adhikari, R.Y., Malvankar, N.S., Pi, S., Ward, J.E., Woodard, T.L., Nevin, K.P., Xia, Q., Tuominen, M.T., Lovley, D.R., 2016. Small 12(33), 4481-4485.

Tian, X., Zhao, F., You, L., Wu, X., Zheng, Z., Wu, R., Jiang, Y., Sun, S., 2017. Phys. Chem. Chem. Phys. 19(3), 1746-1750.

Vellingiri, A., Song, Y.E., Munussami, G., Kim, C., Park, C., Jeon, B.-H., Lee, S.-G., Kim, J.R., 2018. J. Chem. Technol. Biotechnol.

Wang, Q., Jones, A.A.D., Gralnick, J.A., Lin, L., Buie, C.R., 2019. Sci. Adv. 5(1), eaat5664. 
Wang, Z., Zheng, Y., Xiao, Y., Wu, S., Wu, Y., Yang, Z., Zhao, F., 2013. Bioresour. Technol. 144(Supplement C), 74-79.

Wang, Z., Zheng, Z., Zheng, S., Chen, S., Zhao, F., 2015. J. Power Sources 287, 269-275.

Windt, W.D., Aelterman, P., Verstraete, W., 2005. Environ. Microbiol. 7(3), 314-325.

Wright, M.H., Farooqui, S.M., White, A.R., Greene, A.C., 2016. Appl. Environ. Microbiol. 82(17), 5402.

594 Wu, R., Cui, L., Chen, L., Wang, C., Cao, C., Sheng, G., Yu, H., Zhao, F., 2013. Sci. Rep. 3, 3307.

Wu, R., Tian, X., Xiao, Y., Ulstrup, J., Molager Christensen, H.E., Zhao, F., Zhang, J., 2018. J. Mater. Chem. A 596 6(23), 10655-10662.

Wu, R., Wang, C., Shen, J., Zhao, F., 2015. Process Biochem. 50(12), 2061-2065.

Wu, S., Fang, G., Wang, Y., Zheng, Y., Wang, C., Zhao, F., Jaisi, D.P., Zhou, D., 2017. Environ. Sci. Technol. 51(17), 9709-9717.

600

Wu, S., Xiao, Y., Wang, L., Zheng, Y., Chang, K., Zheng, Z., Yang, Z., Varcoe, J.R., Zhao, F., 2014.

601 Electrochim. Acta 146(0), 564-567.

602

Wu, X., Zhao, F., Rahunen, N., Varcoe, J.R., Avignone-Rossa, C., Thumser, A.E., Slade, R.C.T., 2010. Angew. 603 Chem. Int. Ed. 50(2), 427-430.

604

Xiao, Y., Wu, S., Zhang, F., Wu, Y., Yang, Z., Zhao, F., 2013. J. Power Sources 229(0), 79-83.

605

Xiao, Y., Zhang, E., Zhang, J., Dai, Y., Yang, Z., Christensen, H.E.M., Ulstrup, J., Zhao, F., 2017. Sci. Adv. 3(7), e1700623.

607

Yang, Y.-C., Chen, C.-C., Huang, C.-S., Wang, C.-T., Ong, H.-C., 2017. Int. J. Hydrogen Energy 42(34), 608 22235-22242.

609

Yli-Hemminki, P., Jørgensen, K.S., Lehtoranta, J., 2014. Geomicrobiol. J. 31(4), 263-275.

610

Yu, Y., Chen, H., Yong, Y., Kim, D., Song, H., 2011. Chem. Commun. (Camb.) 47(48), 12825-12827.

611 Zhang, Y., Angelidaki, I., 2012a. Biosens. Bioelectron. 35(1), 265-270.

612 Zhang, Y., Angelidaki, I., 2012b. Biosens. Bioelectron. 38(1), 189-194.

613 Zheng, Z., Zheng, Y., Tian, X., Yang, Z., Jiang, Y., Zhao, F., 2018. Environ. Pollut. 241, 265-271. 
614 Zimbardi, L.A., Camargo, F.P., Carli, S., Aquino Neto, S., Meleiro, P.L., Rosa, C.J., De Andrade, R.A., Jorge, 615 A.J., Furriel, P.R., 2016. Int. J. Mol. Sci. 17(5).

616 


\section{Supporting Information}

Electrons selective uptake of a metal-reducing bacterium Shewanella oneidensis MR-1 from ferrocyanide

Zhiyong Zheng, ${ }^{a}$ Yong Xiao, ${ }^{\mathrm{a}}$ Ranran Wu, ${ }^{\mathrm{a}, \mathrm{c}}$ Hans E. Mølager Christensen, ${ }^{\mathrm{a}}$ Feng Zhao, ${ }^{\mathrm{b}}$ and Jingdong Zhang*,a

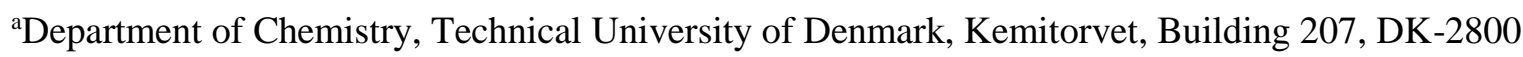

Kongens Lyngby, Denmark.

${ }^{\mathrm{b}}$ CAS Key Laboratory of Urban Pollutant Conversion, Institute of Urban Environment, Chinese Academy of Sciences, 1799 jimei Road, Xiamen 361021, China.

${ }^{\mathrm{c}}$ Tianjin Institute of Industrial Biotechnology, Chinese Academy of Sciences, 32 West 7th Avenue, Tianjin Airport Economic Area, Tianjin 300308, China. 


\section{Contents}

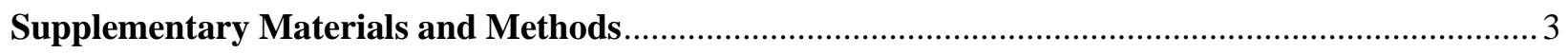

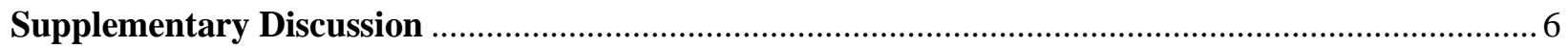

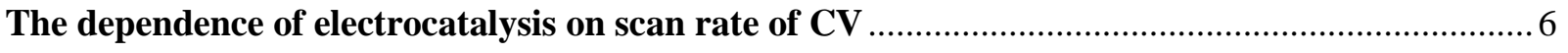

The dependence of electrocatalysis on $\left[\mathrm{Fe}(\mathrm{CN})_{6}\right]^{4-}$ concentration .............................................. 7

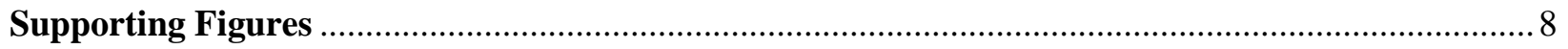

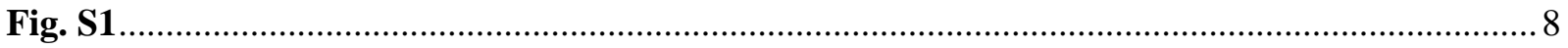

Fig. S2

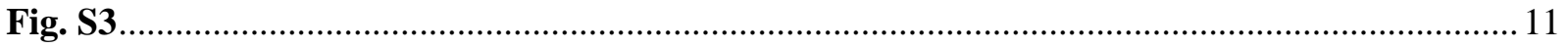

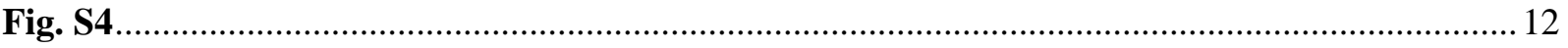

Fig. S5

Fig. S6

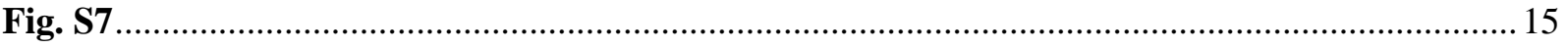

Fig. S8

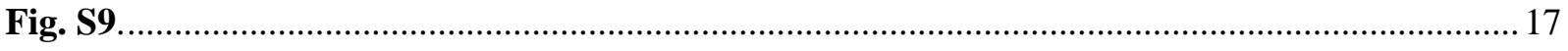

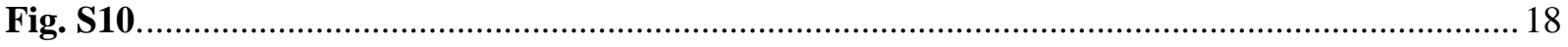

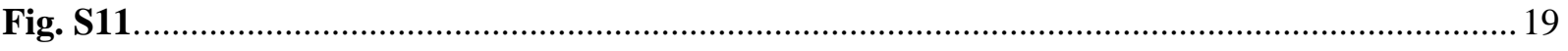

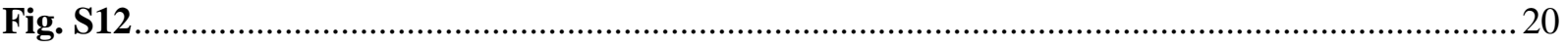

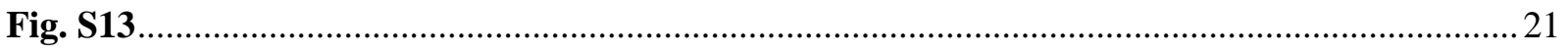

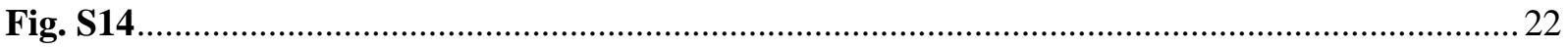

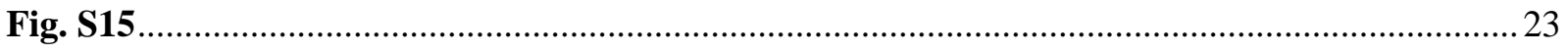

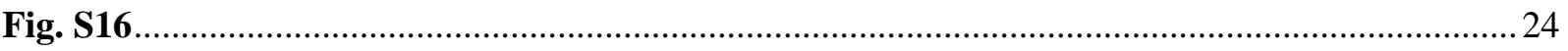

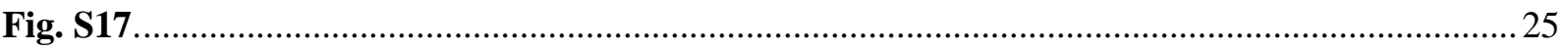

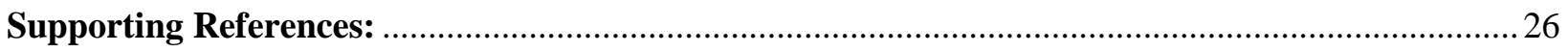

Number of pages: 26

Number of figures: 17 


\section{Supplementary Materials and Methods}

Extraction of extracellular polymeric substances (EPS). The bacteria cells were cultured and harvested by centrifugation $\left(4000 \mathrm{pm}, 10 \mathrm{~min}, 4^{\circ} \mathrm{C}\right)$ and washed twice with $0.9 \% \mathrm{NaCl}(\mathrm{w} / \mathrm{v})$ solution. Washed cell pellets were re-suspended in $0.9 \% \mathrm{NaCl}$ solution and heated in a water bath at $38^{\circ} \mathrm{C}$ for $30 \mathrm{~min}$. Cell suspensions were centrifuged once again $\left(4000 \mathrm{rpm}, 10 \mathrm{~min}, 4^{\circ} \mathrm{C}\right)$ and cell pellets were collected for electrochemical analysis. (Xiao et al. 2017)

Coating of cytochrome c on gold electrodes. A freshly polished gold electrode (Au) was immersed in 1 $\mathrm{mM}$ 6-Mercaptocaproic acid ethanol solution overnight, followed by rinsing with MilliQ water, and the resulted electrode was termed $\mathrm{Au} / 6 \mathrm{C}-\mathrm{HS}$. The $\mathrm{Au} / 6 \mathrm{C}-\mathrm{HS}$ was transferred to cytochrome $c$ (from equine heart) solution (about $40 \mu \mathrm{M}$ in $50 \mathrm{mM}$ PBS, $\mathrm{pH}$ 7.0) for adsorption overnight, obtaining Au/6C-HS/CytC. (Chi et al. 2010)

Coating of riboflavin on GCE. A mixture of $5 \mu \mathrm{L} 30 \mathrm{mM}$ dispersion riboflavin and $5 \mu \mathrm{L} 1 \%$ Nafion solution were mixed and cast on a freshly polished GCE. Then the modified GCE was dried in a fume cupboard under room temperature.

Formation of Pd nanoparticles on MR-1. MR-1 cells were incubated and washed as mentioned before. The washed cells were resuspended into $20 \mathrm{~mL}$ sterilized M9 buffer [pH 7.0; $\mathrm{KH}_{2} \mathrm{PO}_{4}\left(3.00 \mathrm{~g} \mathrm{~L}^{-1}\right)$, $\mathrm{Na}_{2} \mathrm{HPO}_{4} \cdot 12 \mathrm{H}_{2} \mathrm{O}\left(15.14 \mathrm{~g} \mathrm{~L}^{-1}\right), \mathrm{NH}_{4} \mathrm{Cl}\left(1.00 \mathrm{~g} \mathrm{~L}^{-1}\right), \mathrm{NaCl}\left(0.50 \mathrm{~g} \mathrm{~L}^{-1}\right), \mathrm{CaCl}_{2} \cdot 2 \mathrm{H}_{2} \mathrm{O}\left(0.015 \mathrm{~g} \mathrm{~L}^{-1}\right)$, $\left.\mathrm{MgSO}_{4} \cdot 7 \mathrm{H}_{2} \mathrm{O}\left(0.025 \mathrm{~g} \mathrm{~L}^{-1}\right)\right]($ Liu et al. 2016) and deoxygenated with argon. A cell suspension of $1.0 \mathrm{~mL}$ was injected into $24.0 \mathrm{~mL}$ sterilized and deoxygenated M9 buffer containing $18 \mathrm{mM}$ sodium DL-lactate and different concentration of $\mathrm{Na}_{2} \mathrm{PdCl}_{4}(0.08 \mathrm{mM}, 0.40 \mathrm{mM}$, and $0.80 \mathrm{mM})$. The cells were cultured for 1 $\mathrm{h}$ at $30^{\circ} \mathrm{C}$ with a speed of $100 \mathrm{rpm}$. Then the cells were washed and collected for further investigation.

Formation of Pd nanoparticles on GCE. Pd nanoparticles were electrochemically deposited on GCE from $1.0 \mathrm{mM} \mathrm{Na} 2 \mathrm{PdCl}_{4}$ in $50 \mathrm{mM}$ PBS (pH 7.0) by applying a potential of $-1.00 \mathrm{~V}$ vs. $\mathrm{Ag} / \mathrm{AgCl}$ for $5 \mathrm{~min}$ (GCE/Pd_5), $15 \mathrm{~min}\left(\mathrm{GCE} / \mathrm{Pd} \_15\right), 30 \mathrm{~min}\left(\mathrm{GCE} / \mathrm{Pd} \_30\right)$, and $50 \mathrm{~min}\left(\mathrm{GCE} / \mathrm{Pd} \_50\right)$. The Pd nanoparticles 
modified GCE was rinsed with MilliQ water and placed in the electrochemical cell containing with $50 \mathrm{mM}$ PBS (pH 7.0) to verify the presence of Pd nanoparticles by CVs with a scan rate of $100 \mathrm{mV} \mathrm{s}^{-1}$.

Preparation of inactive MR-1. MR-1 cells were incubated in LB medium at $30^{\circ} \mathrm{C}$ with shaking of 100 rpm overnight. Then the cells were washed twice with $0.9 \% \mathrm{NaCl}$. The cells were resuspended with $50 \mathrm{mM}$ PBS (pH 7.0) and packed into a test tube sealed with a blue butyl rubber stopper. The stopper was penetrated with a syringe needle connecting with a sterilized filter $(0.22 \mu \mathrm{m})$ to avoid the pressure change during the freezing process. The test tube was slowly put into liquid nitrogen to freeze cells until the medium became solid. Afterwards, the test tube was taken out and put into water (room temperature) to melt. The freezing and melting process was repeated 20 times to kill the cells while retaining the activity of proteins in the cell membrane.

Morphology characterization. All bacteria for morphology characterization were washed twice with $0.9 \%$ $\mathrm{NaCl}$ unless otherwise stated. Bacteria for scanning electron microscopy (SEM) were resuspended in 2.5\% glutaraldehyde and stored at $4^{\circ} \mathrm{C}$ for $48 \mathrm{~h}$. Afterwards, the cells were washed twice with $50 \mathrm{mM}$ PBS (pH $7.0)$ and further subjected to dehydration in a gradient ethanol series $(50,70,80,95 \%)$ for 15 min each. The cells were dehydrated again with absolute ethanol, 3 changes within 15 minutes. Then the cells were loaded onto a silicon wafer and dried under room temperature overnight. The Pd nanoparticles on GCE were dried under room temperature overnight before SEM observation. Both bacteria and Pd nanoparticles were coated with $1 \mathrm{~nm}$ gold film for SEM observation (Quanta FEG 200 ESEM, FEI, USA). The elemental composition of bacteria and Pd nanoparticles were characterized by energy-dispersive X-ray spectroscopy (EDS) analysis.

Transmission electron microscopy (TEM) samples were cast on lacey carbon-coated copper grids (Ted Pella Inc., Redding CA, USA) by placing one drop of sample dispersion onto grids. Then the samples were observed with a Tecnai G2 T20 instrument (FEI Company, Hillsboro, USA). 
Atomic force microscopy (AFM) measurements were performed using an Agilent 5500 instrument (Agilent Technologies, Chandler, AZ, USA) equipped with a silicon nitride tip (DNP-S10, Bruker, USA) in contact mode in air under ambient conditions. One drop $(4 \sim 10 \mu \mathrm{L})$ of sample dispersion was placed on a cleaned platinum sheet surface and dried in air at ambient temperature at least four hours. (Xiao et al. 2017)

Cell growth monitoring. The growth kinetic of MR-1 and inactive MR-1 was observed by suspending the cells in LB medium to an OD600 of about 0.02 and the cells were incubated at $30^{\circ} \mathrm{C}$ with shaking of $100 \mathrm{rpm}$. Aliquots were sampled at fixed times for optical density measurements using an Agilent 8453 UV-vis spectrophotometer (Santa Clara, USA) with a $1 \mathrm{~cm}$ light path quartz cuvette. All samples were conducted in triplicates. 


\section{Supplementary Discussion}

\section{The dependence of electrocatalysis on scan rate of $\mathrm{CV}$}

Electrocatalysis of $\left[\mathrm{Fe}(\mathrm{CN})_{6}\right]^{4-}$ oxidation displays an asymmetric voltammetry shape. The shape of $\mathrm{CV}$ depends on the scan rate at a given $\left[\mathrm{Fe}(\mathrm{CN})_{6}\right]^{4-}$ concentration. To investigate the effect of scan rate on electrocatalytic oxidation, a series of CVs with scan rate from 0.01 to $3.0 \mathrm{~V} / \mathrm{s}$ were conducted. As shown in Fig. S5A, CV is asymmetric at low scan rates, when the scan rate increased, such asymmetry became vaguer for GCE/MR-1 (Fig. S5B). In contrast, the CVs at all scan rates are symmetric in the same $\left[\mathrm{Fe}(\mathrm{CN})_{6}\right]^{4-}$ solution for bare GCE (Fig. S5C). The ratio of anodic peak current to cathodic peak current $\left(\mathrm{I}_{\mathrm{pa}} / \mathrm{I}_{\mathrm{pc}}\right.$ ) dropped from 7.17 to 1.50 when the scan rate increased from 0.01 to $3.0 \mathrm{~V} \mathrm{~s}^{-1}$ for GCE/MR-1 (Fig. $\mathrm{S} 5 \mathrm{D})$. At high scan rate, the electron transfer speed of $\left[\mathrm{Fe}(\mathrm{CN})_{6}\right]^{4-}$ oxidation is limited by its mass transfer, rather than interfacial electron transfer, where the electrocatalysis occurs. The ability of MR-1 to electrocatalyze $\left[\mathrm{Fe}(\mathrm{CN})_{6}\right]^{4-}$ oxidation is limited by the amount of MR-1. The current through GCE/MR-1 is dominated by the electrocatalysis by MR-1 at low scan rates. At high scan rates, the current is controlled by the diffusion of $\left[\mathrm{Fe}(\mathrm{CN})_{6}\right]^{4-}$ and $\left[\mathrm{Fe}(\mathrm{CN})_{6}\right]^{3-}$ toward the surface of GCE/MR-1. This is further supported by Fig. S5E and F, which show the peak current increased linearly with the square root of scan rate with a larger slope for slow scan rate. (Li et al. 2007) 


\section{The dependence of electrocatalysis on $\left[\mathrm{Fe}(\mathrm{CN})_{6}\right]^{4-}$ concentration}

Influence of the $\left[\mathrm{Fe}(\mathrm{CN})_{6}\right]^{4-}$ concentration on the electrocatalysis is further studied. Different CVs in 0.10 to $20 \mathrm{mM}\left[\mathrm{Fe}(\mathrm{CN})_{6}\right]^{4-}$ were measured. The electrocatalysis is distinct at the low concentration of $\left[\mathrm{Fe}(\mathrm{CN})_{6}\right]^{4-}$ (Fig. S6A) and became obscure in the high concentration (Fig. S6B) for GCE/MR-1. While the CVs are symmetric in all the concentration of $\left[\mathrm{Fe}(\mathrm{CN})_{6}\right]^{4-}\left(\right.$ Fig. S6C) for bare GCE. The $\mathrm{I}_{\mathrm{pa}} / \mathrm{I}_{\mathrm{pc}}$ declined from 21 to 1.43 when the concentration increased from 0.50 to $20 \mathrm{mM}$ (Fig. S6D). It is noteworthy that the cathodic peak is barely detected in $0.1 \mathrm{mM}\left[\mathrm{Fe}(\mathrm{CN})_{6}\right]^{4-}$ (Fig. S6A). This also confirms the limitation of catalysis of $\left[\mathrm{Fe}(\mathrm{CN})_{6}\right]^{4-}$ by MR-1. In high concentration of $\left[\mathrm{Fe}(\mathrm{CN})_{6}\right]^{4-}$, the fraction of the anodic current of electrocatalysis by MR-1 is relatively small and overlapped by the strong signal of the conversion between $\left[\mathrm{Fe}(\mathrm{CN})_{6}\right]^{4-/ 3-}$ redox couple. For GCE/MR-1, the slopes of both anodic and cathodic peak current density vs. $\left[\mathrm{Fe}(\mathrm{CN})_{6}\right]^{4-}$ concentration are completely different between low and high $\left[\mathrm{Fe}(\mathrm{CN})_{6}\right]^{4-}$ concentration. In contrast, slopes are almost the same within experimental uncertainty for GCE (Fig. S6E and Fig. S6F). 


\section{Supporting Figures}

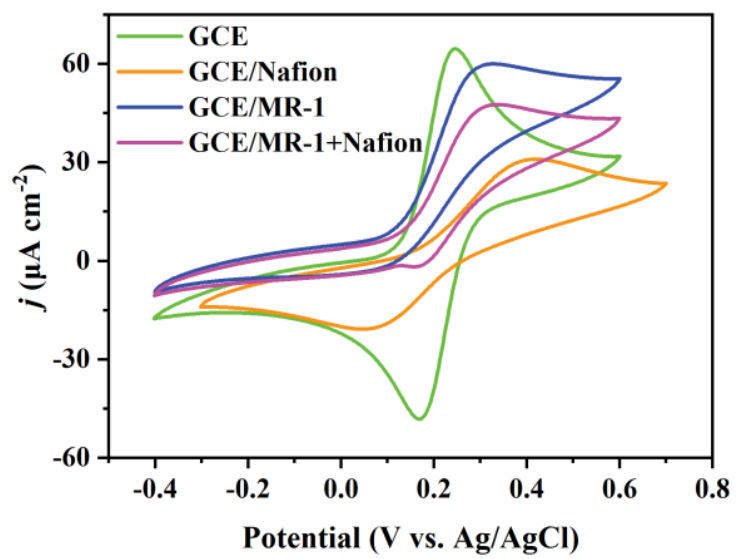

Fig. S1. The effect of Nafion on the conversion of $\mathrm{K}_{4}\left[\mathrm{Fe}(\mathrm{CN})_{6}\right]$. The cyclic voltammetry $(\mathrm{CV})$ on glassy carbon electrode (GCE), GCE coated with Nafion (GCE/Nafion), MR-1 coated on GCE (GCE/MR-1), and the mixture of MR-1 and Nafion coated on GCE (GCE/MR-1 +Nafion). $50 \mathrm{mM}$ PBS (pH 7.0), scan rate $10 \mathrm{mV} \mathrm{s}^{-1}$. 

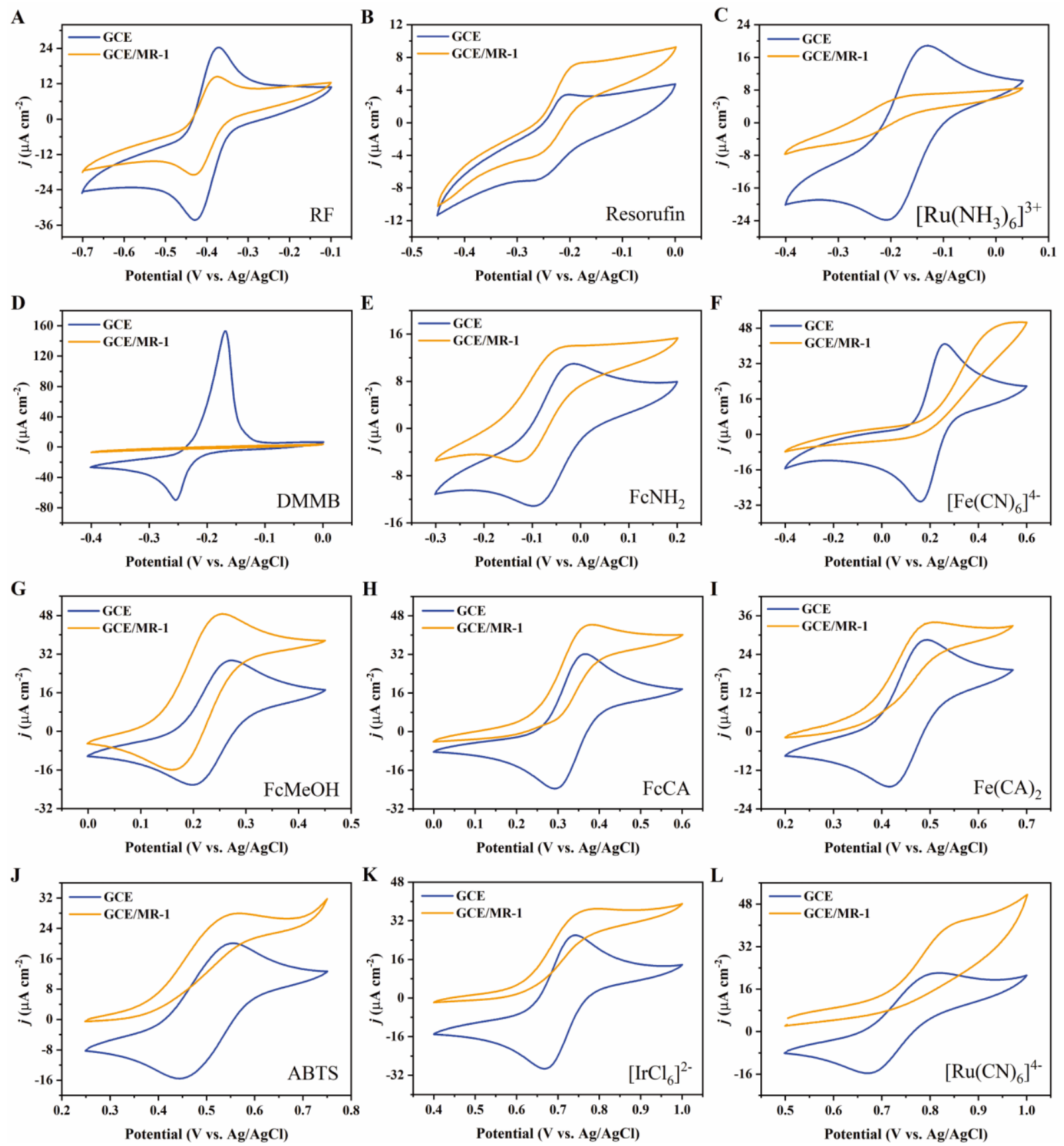

Fig. S2. The conversion of different redox molecules by MR-1. The cyclic voltammetry of (A) $0.25 \mathrm{mM}$ riboflavin $(\mathrm{RF}),(\mathrm{B}) 0.50 \mathrm{mM}$ resorufin, (C) $0.50 \mathrm{mM}\left[\mathrm{Ru}\left(\mathrm{NH}_{3}\right)_{6}\right]^{3+}$, (D) $0.50 \mathrm{mM}$ Taylor's Blue (DMMB), (E) $0.20 \mathrm{mM}$ aminoferrocene $\left(\mathrm{FcNH}_{2}\right)$, (F) $0.50 \mathrm{mM}\left[\mathrm{Fe}(\mathrm{CN})_{6}\right]^{4-},(\mathrm{G})$ $0.50 \mathrm{mM}$ hydroxymethylferrocene $(\mathrm{FcMeOH}),(\mathrm{H}) 0.50 \mathrm{mM}$ ferrocenecarboxylic acid (FcCA), (I) 
$\left.0.50 \mathrm{mM} \mathrm{1,1'-ferrocenedicarboxylic} \mathrm{acid} \mathrm{(} \mathrm{Fc}(\mathrm{CA})_{2}\right),(\mathrm{J}) 0.50 \mathrm{mM}$ azino-di-[3-ethylbenzthiazoline sulfonate (6)] (ABTS), (K) $0.50 \mathrm{mM}\left[\mathrm{IrCl}_{6}\right]^{2-}$, (L) $0.50 \mathrm{mM}\left[\mathrm{Ru}(\mathrm{CN})_{6}\right]^{4-}$ on GCE, and GCE/MR1. The inconsistent concentrations of riboflavin and aminoferrocene are due to poor water solubilities. The electrolyte $50 \mathrm{mM}$ PBS (pH 7.0), scan rate $10 \mathrm{mV} \mathrm{s}^{-1}$. 


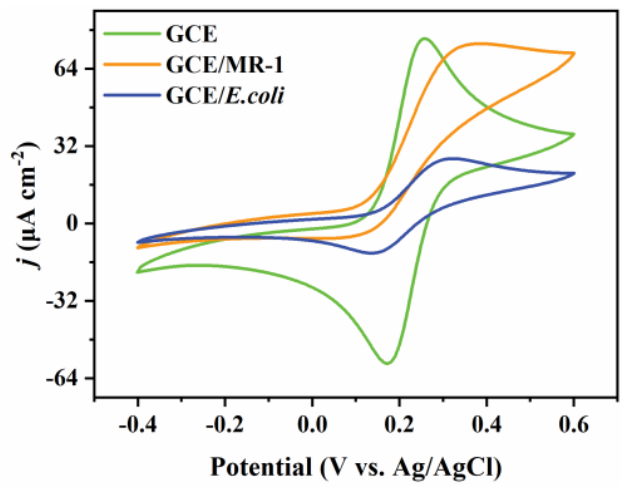

Fig. S3. The conversion of $\left[\mathrm{Fe}(\mathrm{CN})_{6}\right]^{4-}$ by different bacteria. The cyclic voltammetry $(\mathrm{CV})$ on glassy carbon electrode (GCE), MR-1 coated on GCE (GCE/MR-1), and E. coli K-12 coated on GCE (GCE/E.coli) in $1 \mathrm{mM}\left[\mathrm{Fe}(\mathrm{CN})_{6}\right]^{4-} .50 \mathrm{mM}$ PBS (pH 7.0), scan rate $10 \mathrm{mV} \mathrm{s}^{-1}$. 


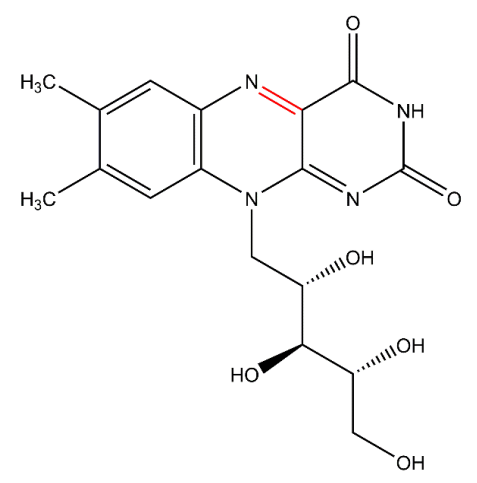

Oxidized riboflavin

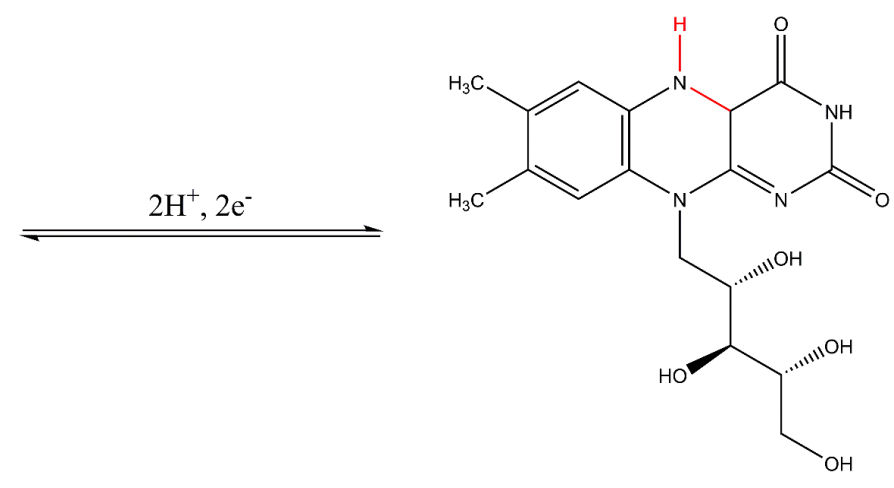

Reduced riboflavin

Fig. S4. The riboflavin redox system 

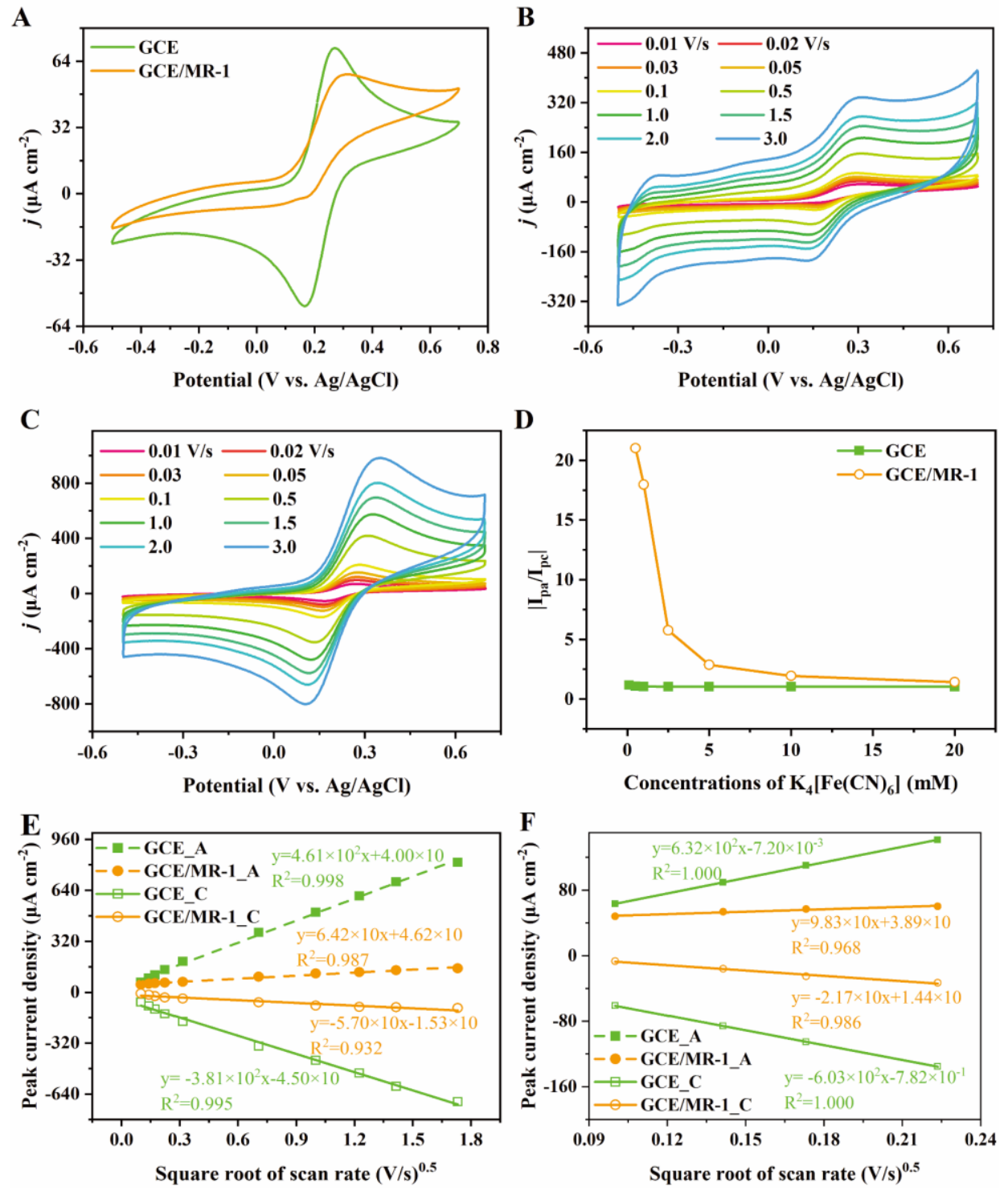

Fig. S5. Scan rate-dependent conversion of $\left[\mathrm{Fe}(\mathrm{CN})_{6}\right]^{4-}$ by MR-1. (A) The cyclic voltammetry on MR-1 coated on GCE (GCE/MR-1) in $1.0 \mathrm{mM}\left[\mathrm{Fe}(\mathrm{CN})_{6}\right]^{4-}$ at $0.01 \mathrm{~V} \mathrm{~s}^{-1}$. The cyclic voltammetry on (B) MR-1 coated on GCE (GCE/MR-1) and (C) bare GCE in $1.0 \mathrm{mM}\left[\mathrm{Fe}(\mathrm{CN})_{6}\right]^{4-}$ at different scan rates. (D) The ratio of anodic peak current ( $\left.\mathrm{I}_{\mathrm{pa}}\right)$ to cathodic peak current $\left(\mathrm{I}_{\mathrm{ca}}\right)$ in $(\mathrm{b})$. (E) the plots of peak current density vs. the square root of scan rate in the range $0.01 \sim 3.0 \mathrm{~V} \mathrm{~s}^{-1}$. (F) the plots of peak current density vs. the square root of scan rate in the range $0.01 \sim 0.05 \mathrm{~V} \mathrm{~s}^{-1}$. The electrolyte $50 \mathrm{mM}$ PBS (pH 7.0). 

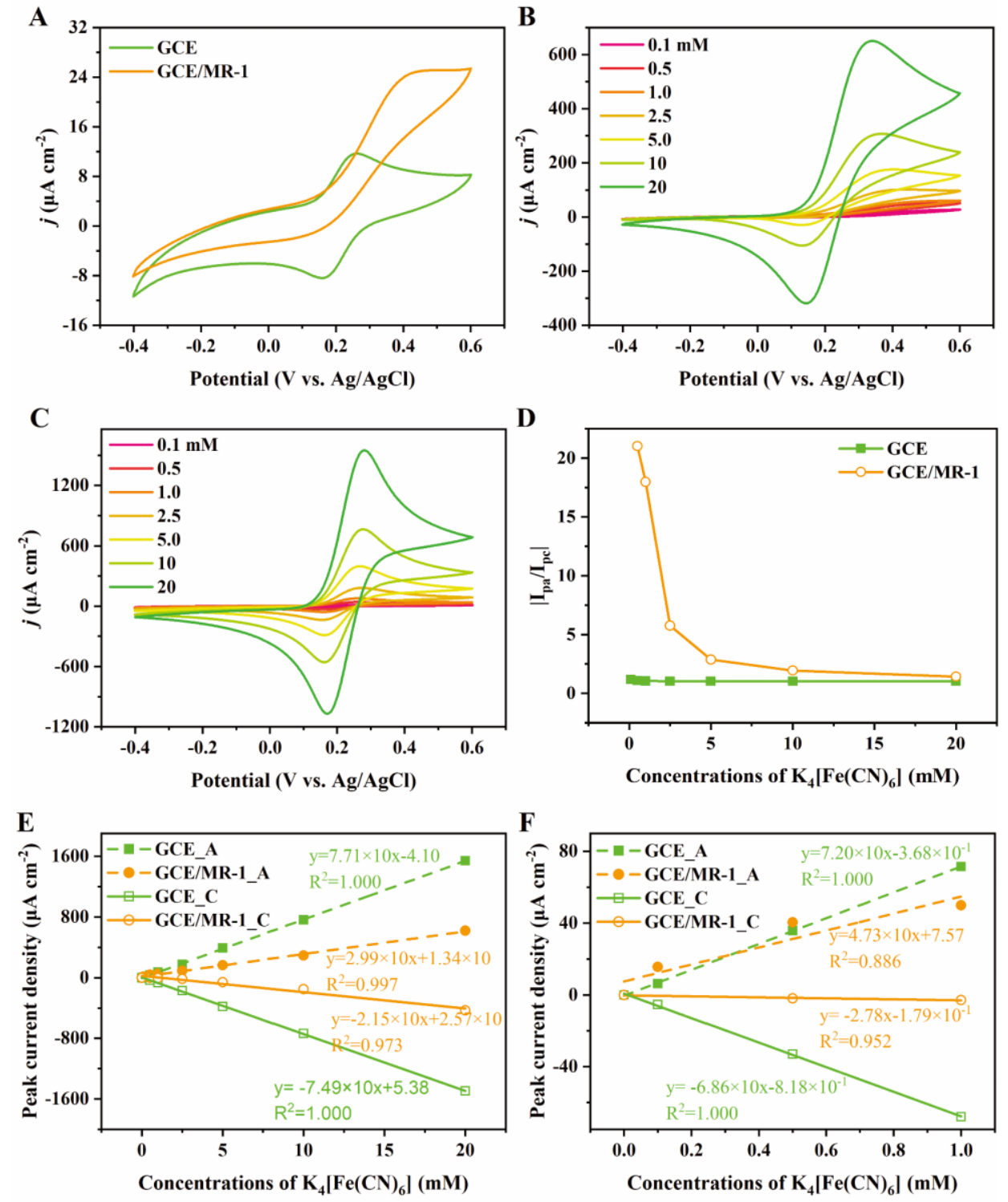

Fig. S6. Conversion of $\left[\mathrm{Fe}(\mathrm{CN})_{6}\right]^{4-}$ by MR-1 in different concentration of $\left[\mathrm{Fe}(\mathrm{CN})_{6}\right]^{4-}$. (A) The cyclic voltammetry on MR-1 coated on GCE (GCE/MR-1) in $0.1 \mathrm{mM}\left[\mathrm{Fe}(\mathrm{CN})_{6}\right]^{4-}$. The cyclic voltammetry on (B) MR-1 coated on GCE (GCE/MR-1) and (C) bare GCE in different concentration of $\left[\mathrm{Fe}(\mathrm{CN})_{6}\right]^{4-}$. (D) The ratio of anodic peak current $\left(\mathrm{I}_{\mathrm{pa}}\right)$ to cathodic peak current $\left(\mathrm{I}_{\mathrm{ca}}\right)$ in $(\mathrm{B})$. (E) The plots of peak current density vs. the concentration of $\left[\mathrm{Fe}(\mathrm{CN})_{6}\right]^{4-}$ from $0.1 \sim 20$ mM. (F) The plots of peak current density vs. the concentration of $\left[\mathrm{Fe}(\mathrm{CN})_{6}\right]^{4-}$ from $0.1 \sim 1.0 \mathrm{mM}$. The electrolyte $50 \mathrm{mM}$ PBS (pH 7.0). 

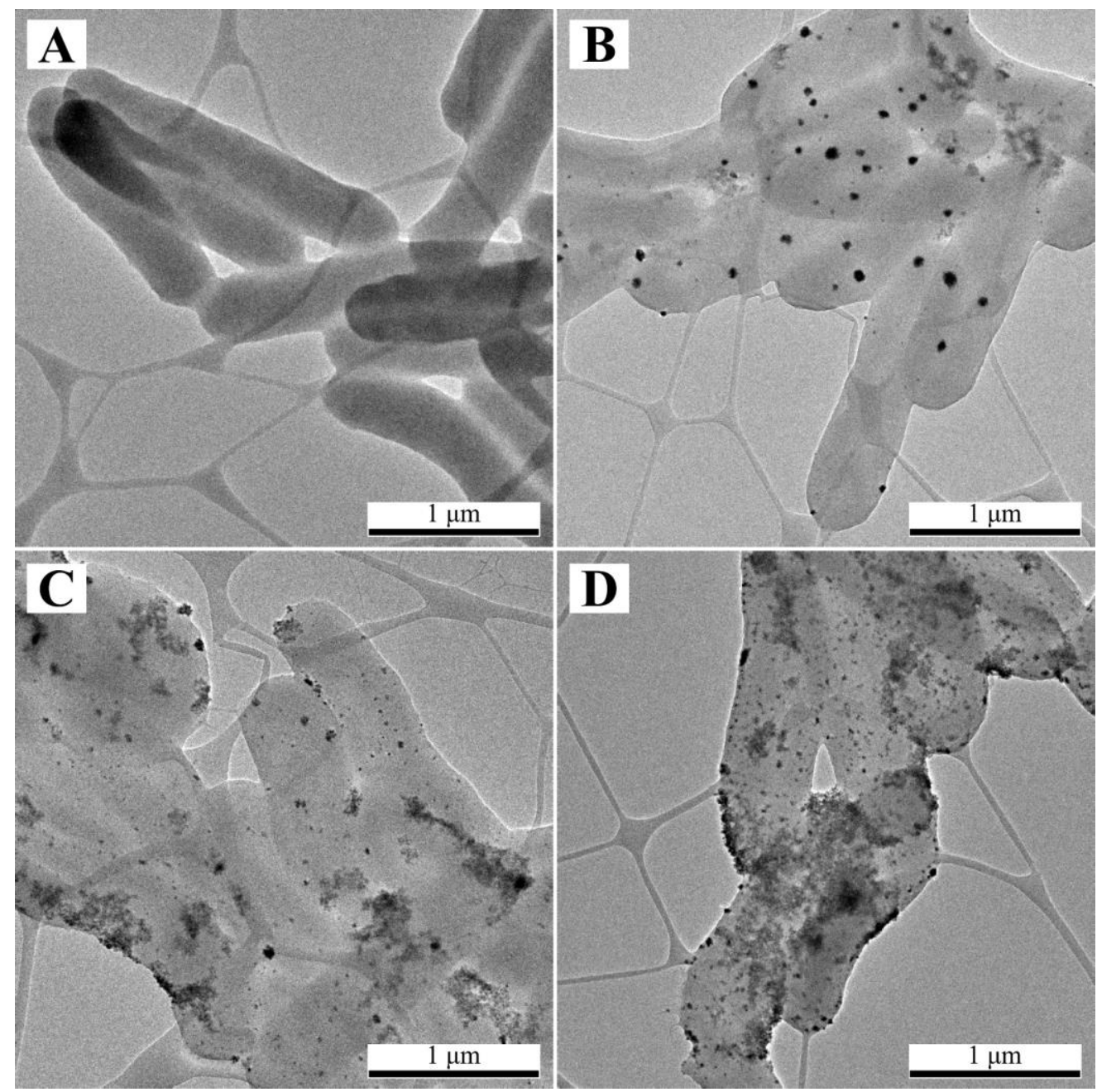

Fig. S7. TEM images of MR-1 and Pd nanoparticles on MR-1. (A) MR-1 cultured in M9 medium without $\left[\mathrm{PdCl}_{4}\right]^{2-}$. (B) MR-1 cultured in M9 medium with $0.08 \mathrm{mM}\left[\mathrm{PdCl}_{4}\right]^{2-}(\mathrm{MR}-1+\mathrm{Pd})$. (C) MR1 cultured in M9 medium with $0.40 \mathrm{mM}\left[\mathrm{PdCl}_{4}\right]^{2-}(\mathrm{MR}-1++\mathrm{Pd})$. (D) MR-1 cultured in M9 medium with $0.80 \mathrm{mM}\left[\mathrm{PdCl}_{4}\right]^{2-}(\mathrm{MR}-1+++\mathrm{Pd})$. The black dots are Pd nanoparticles. 


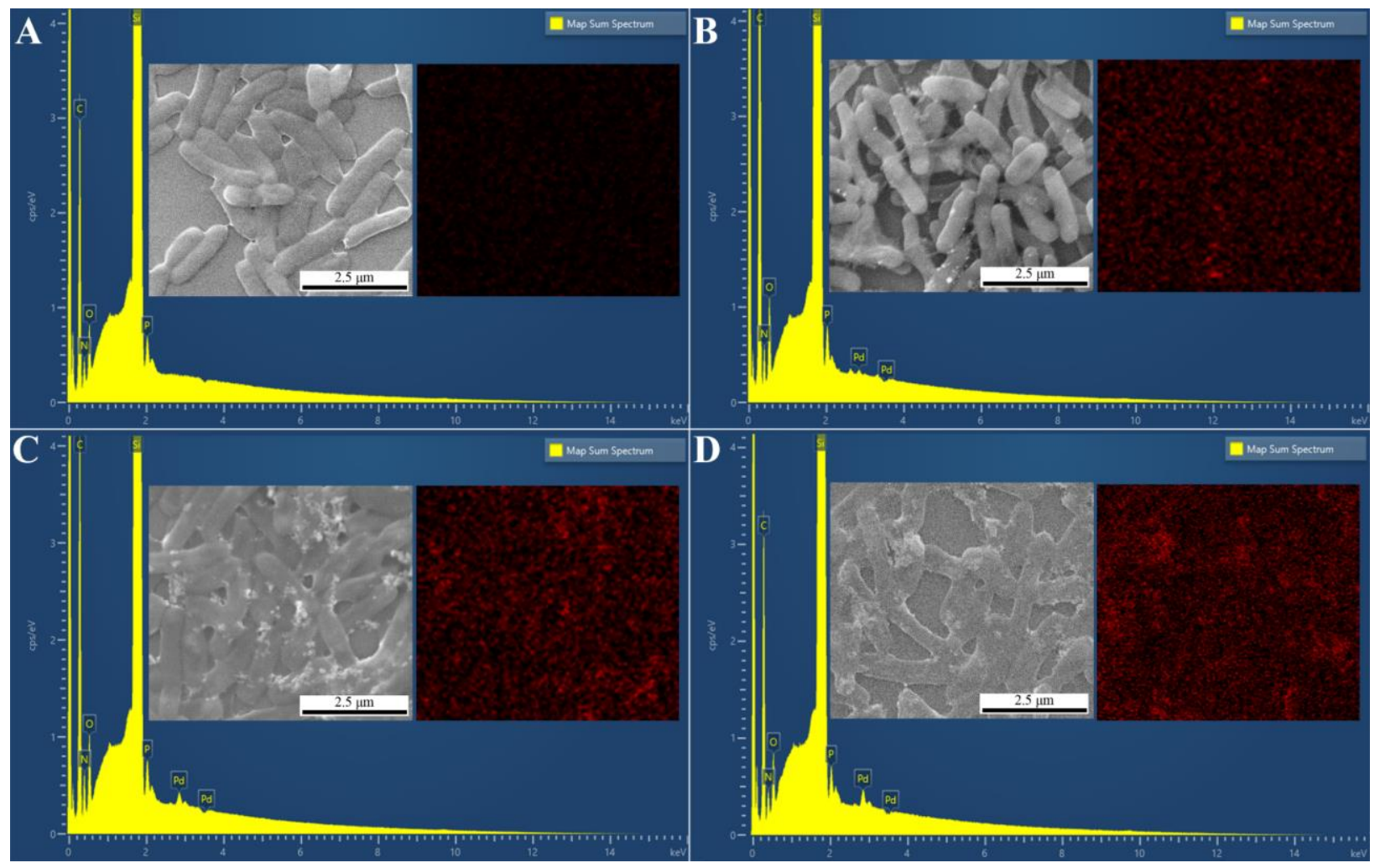

Fig. S8. EDS spectrum, SEM and corresponding EDS mapping patterns (insert) of MR-1 with Pd nanoparticles with different concentration. (A) MR-1 cultured in M9 medium without $\left[\mathrm{PdCl}_{4}\right]^{2-}$. (B) MR-1 cultured in M9 medium with $\left.0.08 \mathrm{mM}_{[\mathrm{PdCl}}\right]^{2-}(\mathrm{MR}-1+\mathrm{Pd})$. (C) MR-1 cultured in M9 medium with $0.4 \mathrm{mM}\left[\mathrm{PdCl}_{4}\right]^{2-}(\mathrm{MR}-1++\mathrm{Pd})$. (D) MR-1 cultured in M9 medium with $0.8 \mathrm{mM}$ $\left[\mathrm{PdCl}_{4}\right]^{2-}(\mathrm{MR}-1+++\mathrm{Pd})$. 
A

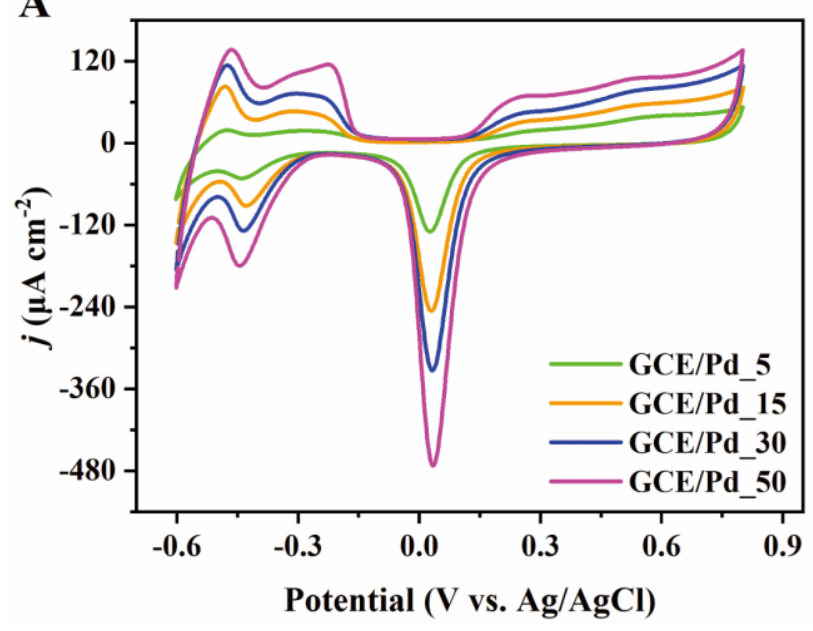

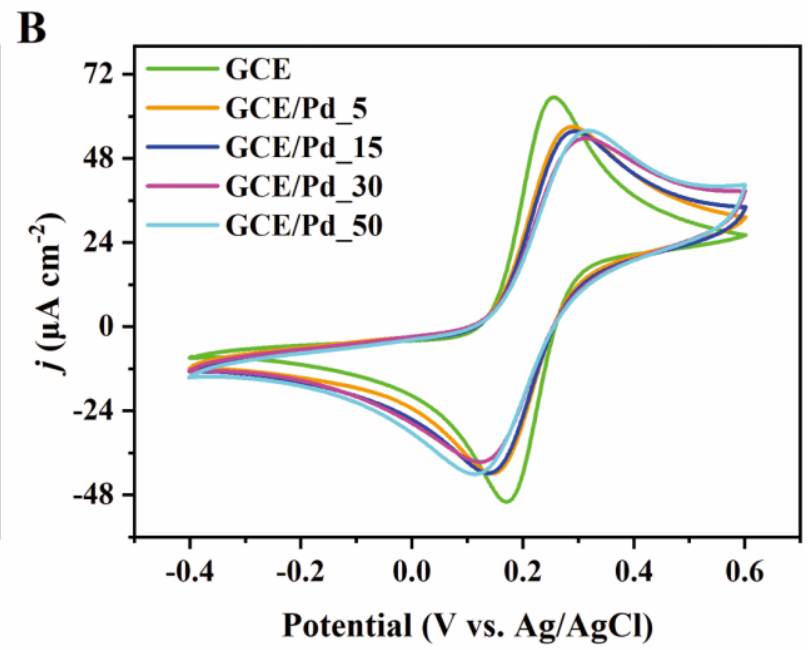

Fig. S9. Conversion of $\left[\mathrm{Fe}(\mathrm{CN})_{6}\right]^{4-}$ by Pd nanoparticles. (A) CV of Pd nanoparticles coated on GCE for 5 min (GCE/Pd_5), $15 \min \left(\mathrm{GCE} / \mathrm{Pd} \_15\right), 30 \mathrm{~min}\left(\mathrm{GCE} / \mathrm{Pd} \_30\right)$ and $50 \mathrm{~min}\left(\mathrm{GCE} / \mathrm{Pd} \_50\right)$ in $0.1 \mathrm{mM}\left[\mathrm{PdCl}_{4}\right]^{2-}$. Scan rate: $100 \mathrm{mV} \mathrm{s}^{-1}$. (B) $\mathrm{CVs}$ of $1 \mathrm{mM}\left[\mathrm{Fe}(\mathrm{CN})_{6}\right]^{4-}$ on the electrodes in (A). The scan rate $10 \mathrm{mV} \mathrm{s}^{-1}$. The electrolyte $50 \mathrm{mM}$ PBS (pH 7.0). 

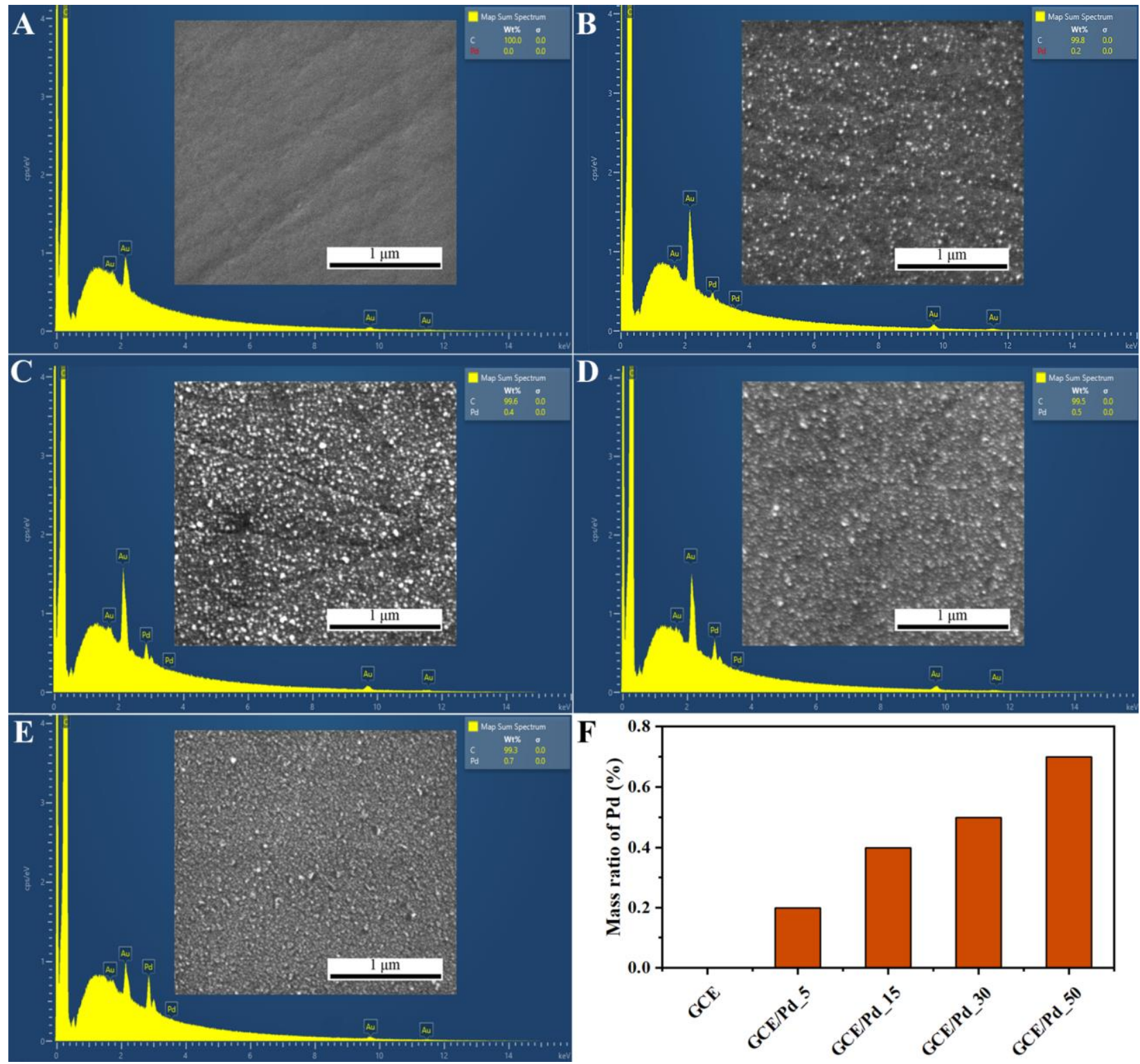

Fig. S10. EDS spectrum and SEM (insert) of different amount of Pd nanoparticles on GCE. (A) clean GCE surface. (B) Pd nanoparticles coated on GCE for $5 \mathrm{~min}$ (GCE/Pd_5). (C) Pd nanoparticles coated on GCE for 15 min (GCE/Pd_15). (D) Pd nanoparticles coated on GCE for 30 min (GCE/Pd_30). (E) Pd nanoparticles coated on GCE for 50 min (GCE/Pd_50). (F) The summary of mass ratio of $\mathrm{Pd}$ on the different samples in $\mathrm{A} \sim \mathrm{E}$. Note the peaks belonging to $\mathrm{Au}$ were caused by Au coating during SEM preparation, therefore, Au is excluded in the map sum spectrum table. 


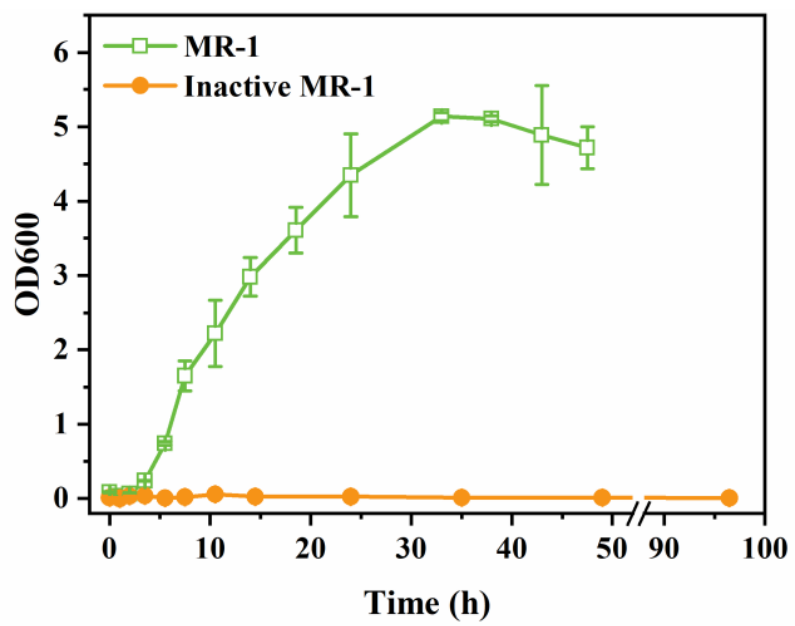

Fig. S11. Growth curves of MR-1 and repeatedly frozen MR-1 (inactive MR-1) in LB medium. 

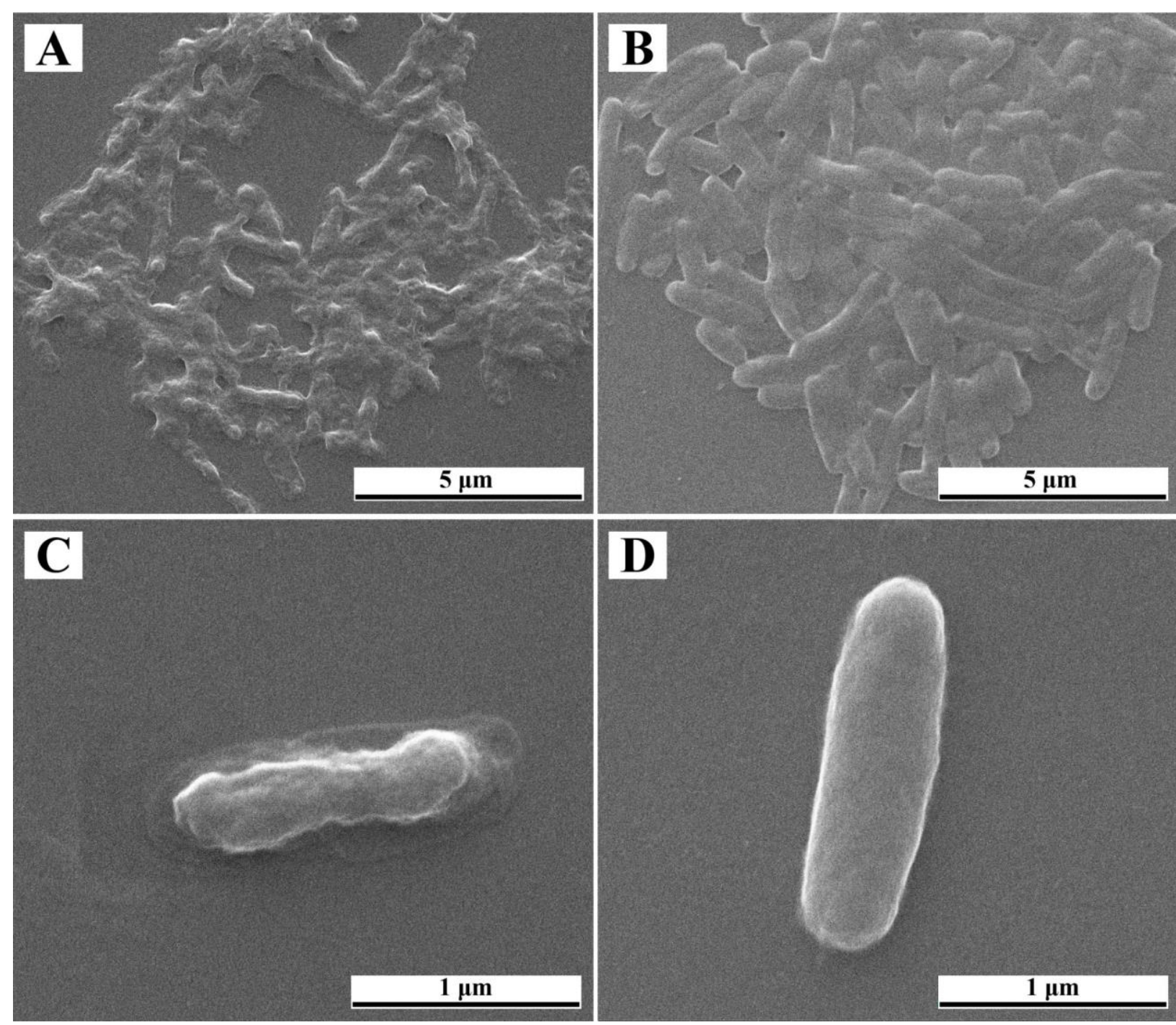

Fig. S12. SEM of MR-1 before and after freezing. SEM of (A and C) repeatedly frozen MR-1 (inactive MR-1) and (B and D) MR-1 before freezing. 

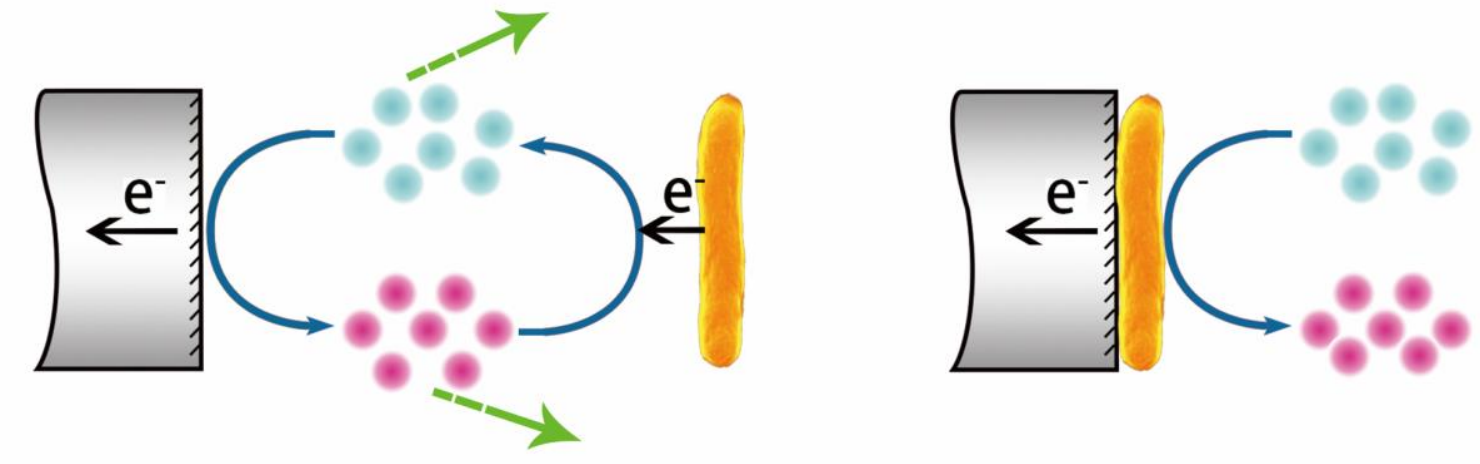

$\left[\mathrm{Fe}(\mathrm{CN})_{6}\right]^{4-}$

\section{$\left[\mathrm{Fe}(\mathrm{CN})_{6}\right]^{3-}$}

Fig. S13. Two different models of $\left[\mathrm{Fe}(\mathrm{CN})_{6}\right]^{4-/ 3-}$ in the interaction with MR-1. (A) Mediating model, in which $\left[\mathrm{Fe}(\mathrm{CN})_{6}\right]^{4-3-}$ act as a redox mediator between MR-1 and electrode. $\left[\mathrm{Fe}(\mathrm{CN})_{6}\right]^{4-3-}$ can diffuse into the bulk electrolyte if the space between the MR-1 layer and the electrode is big or not isolated (green dotted arrows). (B) Electrocatalysis model, in which $\left[\mathrm{Fe}(\mathrm{CN})_{6}\right]^{4-3-}$ act as the reactant/product of the electrocatalysis by MR-1. 


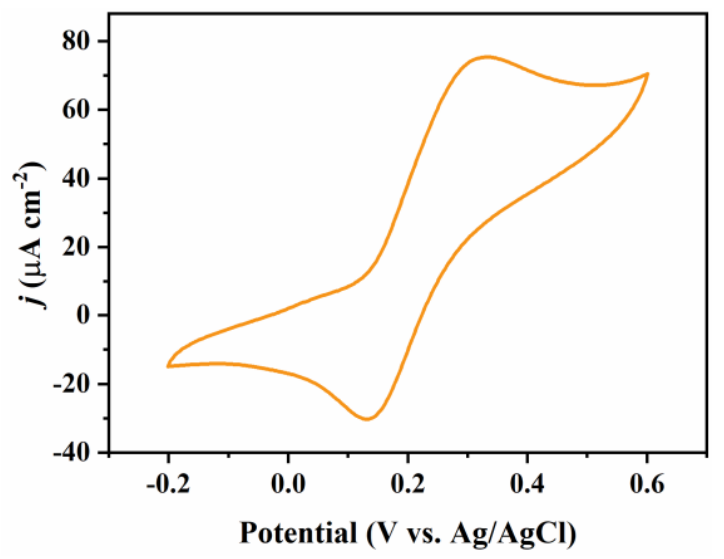

Fig. S14. The conversion of $\mathrm{K}_{3}\left[\mathrm{Fe}(\mathrm{CN})_{6}\right]$ on MR-1. The CV of GCE/MR-1 in $1 \mathrm{mM} \mathrm{K}_{3}\left[\mathrm{Fe}(\mathrm{CN})_{6}\right]$ and $9 \mathrm{mM}$ glucose at $50 \mathrm{mV} \mathrm{s}^{-1}$. The electrolyte $50 \mathrm{mM}$ PBS (pH 7.0) 


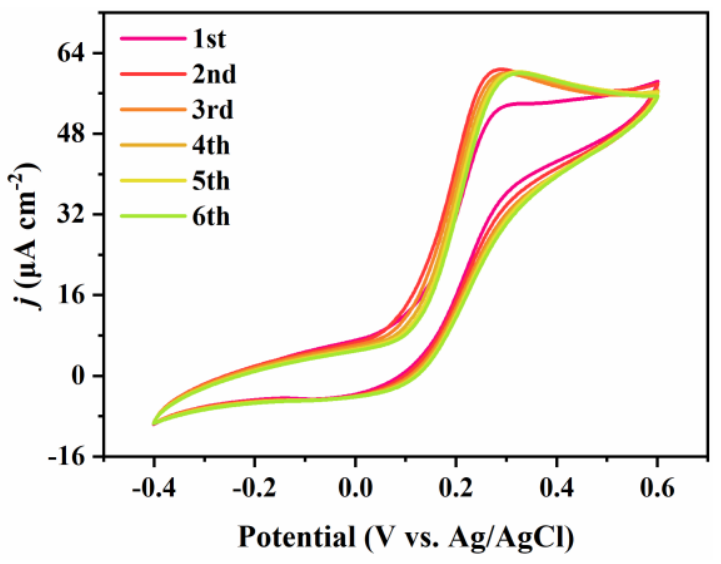

Fig. S15. The first to the sixth scan of cyclic voltammetry $(\mathrm{CV})$ of the conversion of $\left[\mathrm{Fe}(\mathrm{CN})_{6}\right]^{4-}$ by MR-1. The CV on MR-1 coated glassy carbon electrode (GCE/MR-1) in $1 \mathrm{mM}\left[\mathrm{Fe}(\mathrm{CN})_{6}\right]^{4-} .50$ $\mathrm{mM}$ PBS (pH 7.0), scan rate $10 \mathrm{mV} \mathrm{s}^{-1}$. 


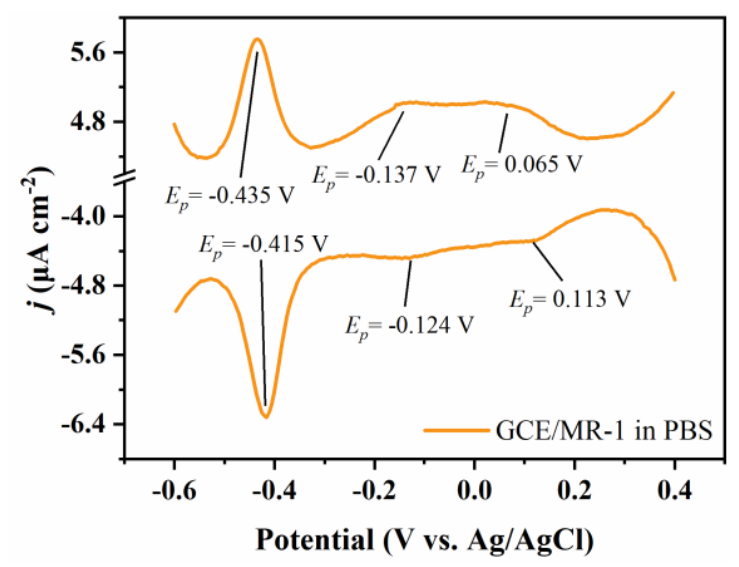

Fig. S16. Differential pulse voltammetry (DPV) of MR-1 cells coated on a GCE 


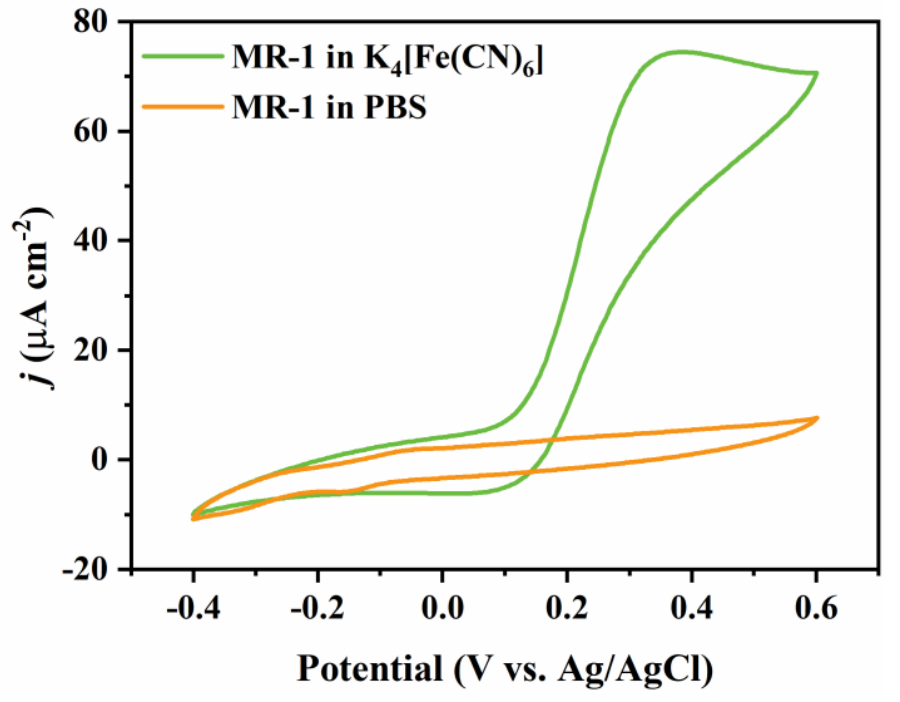

Fig. S17. The comparison of electrochemical signal of GCE/MR-1 in PBS and PBS containing $1 \mathrm{mM}\left[\mathrm{Fe}(\mathrm{CN})_{6}\right]^{4-}$. Scan rate $10 \mathrm{mV} \mathrm{s}^{-1}$. 


\section{Supporting References:}

Chi, Q., Zhang, J., Arslan, T., Borg, L., Pedersen, G.W., Christensen, H.E.M., Nazmudtinov, R.R., Ulstrup, J., 2010. J. Phys. Chem. B 114(16), 5617-5624.

Li, J., Qiu, J., Xu, J., Chen, H., Xia, X., 2007. Adv. Funct. Mater. 17(9), 1574-1580.

Liu, J., Zheng, Y., Hong, Z., Cai, K., Zhao, F., Han, H., 2016. Sci. Adv. 2(9), e1600858.

Xiao, Y., Zhang, E., Zhang, J., Dai, Y., Yang, Z., Christensen, H.E.M., Ulstrup, J., Zhao, F., 2017. Sci. Adv. 3(7), e1700623. 